\title{
Mechanism of Cellular Formation and In Vivo Seeding Effects of Hexameric $\beta$-Amyloid Assemblies
}

\author{
Céline Vrancx ${ }^{1}$ - Devkee M. Vadukul ${ }^{1} \cdot$ Nuria Suelves $^{1} \cdot$ Sabrina Contino $^{1} \cdot$ Ludovic D'Auria $^{2} \cdot$ Florian Perrin $^{1}$. \\ Vincent van Pesch ${ }^{2} \cdot$ Bernard Hanseeuw $^{3} \cdot$ Loïc Quinton $^{4} \cdot$ Pascal Kienlen-Campard $^{1}$ (D)
}

Received: 27 May 2021 / Accepted: 14 September 2021 / Published online: 4 October 2021

(c) The Author(s) 2021

\begin{abstract}
The $\beta$-amyloid peptide (A $\beta$ ) is found as amyloid fibrils in senile plaques, a typical hallmark of Alzheimer's disease (AD). However, intermediate soluble oligomers of $A \beta$ are now recognized as initiators of the pathogenic cascade leading to AD. Studies using recombinant $A \beta$ have shown that hexameric $A \beta$ in particular acts as a critical nucleus for $A \beta$ self-assembly. We recently isolated hexameric $A \beta$ assemblies from a cellular model, and demonstrated their ability to enhance $A \beta$ aggregation in vitro. Here, we report the presence of similar hexameric-like $\mathrm{A} \beta$ assemblies across several cellular models, including neuronal-like cell lines. In order to better understand how they are produced in a cellular context, we investigated the role of presenilin-1 (PS1) and presenilin-2 (PS2) in their formation. PS1 and PS2 are the catalytic subunits of the $\gamma$-secretase complex that generates A $\beta$. Using CRISPR-Cas9 to knockdown each of the two presenilins in neuronal-like cell lines, we observed a direct link between the PS2-dependent processing pathway and the release of hexameric-like A $\beta$ assemblies in extracellular vesicles. Further, we assessed the contribution of hexameric A $\beta$ to the development of amyloid pathology. We report the early presence of hexameric-like $\mathrm{A} \beta$ assemblies in both transgenic mice brains exhibiting human $\mathrm{A} \beta$ pathology and in the cerebrospinal fluid of $\mathrm{AD}$ patients, suggesting hexameric $\mathrm{A} \beta$ as a potential early AD biomarker. Finally, cellderived hexameric $A \beta$ was found to seed other human $A \beta$ forms, resulting in the aggravation of amyloid deposition in vivo and neuronal toxicity in vitro.
\end{abstract}

Keywords Alzheimer's disease $\cdot A \beta$ oligomers $\cdot$ Hexameric A $\beta \cdot$ Presenilins $\cdot$ FAD model $\cdot$ Seeding

\begin{tabular}{ll} 
Abbreviations \\
$\mathrm{A} \beta$ & $\beta$-Amyloid \\
$\mathrm{AD}$ & Alzheimer's disease \\
$\mathrm{AICD}$ & APP intracellular domain \\
& \\
\hline
\end{tabular}

Nuria Suelves and Sabrina Contino contributed equally to this work.

Pascal Kienlen-Campard

pascal.kienlen-campard@uclouvain.be

1 Alzheimer Research Group, Cellular and Molecular Division (CEMO), Institute of Neuroscience, Université Catholique de Louvain, 1200 Brussels, Belgium

2 Neurochemistry Unit, Cellular and Molecular Division (CEMO), Institute of Neuroscience, Université Catholique de Louvain, 1200 Brussels, Belgium

3 Department of Neurology, Cliniques Universitaires Saint-Luc, Université Catholique de Louvain, 1200 Brussels, Belgium

4 Laboratory of Mass Spectrometry, Department of Chemistry, Université de Liège, 4000 Liège, Belgium

$\begin{array}{ll}\text { APP } & \text { Amyloid precursor protein } \\ \text { CHO } & \text { Chinese hamster ovary } \\ \text { CRISPR } & \text { Clustered regularly interspaced short palindro- } \\ & \text { mic repeats } \\ \text { Cryo-EM } & \text { Cryo-electron microscopy } \\ \text { CSF } & \text { Cerebrospinal fluid } \\ \text { CTF } & \text { C-terminal fragment } \\ \text { HEK } & \text { Human embryonic kidney } \\ \text { KD } & \text { knockdown } \\ \text { MCI } & \text { Mild cognitive impairment } \\ \text { PET } & \text { Positron-emission tomography } \\ \text { PSEN } & \text { Presenilin (gene) } \\ \text { PS } & \text { Presenilin (protein) } \\ \text { R } & \text { Rescued } \\ \text { S } & \text { Scrambled } \\ \text { sAPP } & \text { Soluble APP } \\ \text { ThT } & \text { Thioflavin T } \\ \text { WT } & \text { Wild-type }\end{array}$




\section{Introduction}

The $\beta$-amyloid peptide (A $\beta$ ) is the major constituent of senile plaques, a typical histological hallmark of Alzheimer's disease (AD). This peptide is produced by the amyloidogenic processing of the amyloid precursor protein (APP) [1]. APP undergoes a first cleavage by $\beta$-secretase, producing a 99 -amino acid membrane-bound $\mathrm{C}$-terminal fragment ( $\beta \mathrm{CTF}$ or $\mathrm{C} 99$ ), which in turn is cleaved by $\gamma$-secretase to generate the intracellular domain of APP (AICD) and $A \beta$. To note, different isoforms of $A \beta$ can be produced, mostly ranging from 38 to 43 amino acids [2]. After its release as a monomer, $A \beta$ and particularly its longer forms such as $A \beta_{42}$, has the propensity to selfassemble [3]. This leads to the formation of $A \beta$ oligomers and ultimately amyloid fibrils, aggregating into senile plaques in the brain.

Many studies suggest that the toxicity of $A \beta$ is not related to insoluble fibrils but rather to soluble oligomeric intermediates generated during fibrillogenesis. Such a toxic property for $A \beta$ oligomers may result from their intrinsically misfolded nature and their aggregation propensity that can together contribute to trap vital proteins or cause cell membrane alterations $[4,5]$. In addition, it is believed that the stability of $A \beta$, and particularly of $A \beta$ oligomers, gives them persistent and aggravating pathological properties for the formation of amyloid deposits $[6,7]$.

Several oligomeric $A \beta$ species have been suggested to play an important role in the process of $\mathrm{A} \beta$ self-assembly. Among them, $A \beta$ hexamers gain increasing interest. They are smallest assembly readily formed by synthetic $A \beta_{42}$ in solution $[3,8]$. $\mathrm{A} \beta$ assembly relies on a process of nucleated polymerization $[9,10]$, involving a nucleation phase where $\mathrm{A} \beta$ monomers self-associate to form an oligomeric nucleus. Findings from structural studies indicate that hexameric $A \beta$ assemblies might behave as such nuclei, serving as a building block for the formation of higher assemblies [11-13]. However, the cellular context leading to the formation of hexameric $A \beta$ assemblies is still poorly understood.

We previously reported the presence of $\sim 28 \mathrm{kDa} A \beta$ assemblies in Chinese hamster ovary (CHO) cells expressing amyloidogenic fragments of human APP [14]. Biochemical approaches demonstrated that these assemblies likely correspond to $A \beta_{42}$ hexamers [15]. Here, we report the identification of similar, hexameric-like, $A \beta$ assemblies across several cell lines, including a neuronal-like cell line. We studied the cellular pathway that potentially contributes to hexameric $\mathrm{A} \beta$ formation and propagation. The production of $A \beta$ in a cellular context relies on the $\gamma$-secretase activity. The catalytic core of the $\gamma$-secretase complex is formed by either the presenilin-1 (PS1) or the presenilin-2 (PS2) protein [16]. PS1 has been repeatedly reported as the major contributor to $A \beta$ production [17-21], rendering the role of PS2 in amyloid pathology less understood. Recent findings revealed the enrichment of PS $2 \gamma$-secretases in endosomal compartments [22]. A lower contribution of PS2 to overall A $\beta$ production could thus be explained by a secondary encountering of substrates along cellular trafficking. Importantly, PS2 $\gamma$-secretases were shown to generate mostly an intracellular pool of $A \beta$ and to favor the accumulation of aggregation-prone $A \beta_{42}$ in endocytic compartments [23]. Based on these observations, we aimed at discriminating the contribution of PS1 and PS $2 \gamma$-secretases to the production of the $A \beta$ assemblies we identified. We generated human neuronal-like cell lines knockdown for each of the two presenilins and provide evidence for a specific correlation between the PS2-dependent $\gamma$-secretase and the vesicular release of hexameric-like $\mathrm{A} \beta$ assemblies. This suggests a key role for the $\gamma$-secretase present in the late endosomal/ lysosomal compartments both in the production and in the mode of release of $A \beta$ oligomers.

As different species of $A \beta$ oligomers were suggested to exert neurotoxic effects [24-28], a crucial point was then to understand if the identified hexameric-like $A \beta$ assemblies produced and released by cells readily appeared in pathological conditions, and if they displayed toxic properties. We found hexameric-like $A \beta$ to be present in the $5 \mathrm{xFAD}$ mouse model of amyloid pathology [29] and the cerebrospinal fluid of human AD patients. This reinforces the role of $A \beta$ hexamers in pathological conditions. We further assessed the ability of hexameric $A \beta$ isolated from cells to drive amyloid deposition and induce neuronal toxicity. To this end, we used two mouse models: control wild-type mice (C57BL/6) to measure the ability of the hexamers to form amyloid deposits in a non-pathological context, and transgenic 5xFAD mice to study their effect in an environment where $A \beta$ is pre-existing. We found that cell-derived hexameric $A \beta$ does not induce toxic effects by itself, but enhances $A \beta$ deposition in a pathological context where human $\mathrm{A} \beta$ accumulates (5xFAD).

\section{Materials and Methods}

\section{Chemicals and Reagents}

Reagents used for Western blotting-Pierce BCA protein assay kit, SeeBlue ${ }^{\mathrm{TM}}$ Plus2 pre-stained standard, NuPAGE ${ }^{\mathrm{TM}}$ 4-12\% Bis-Tris protein gels, NuPAGETM MES SDS Running Buffer $(20 \times)$, NuPAGETM Transfer Buffer $(20 \times)$, nitrocellulose $0.1 \mu \mathrm{m}$ membranes, and GE Healthcare ECL Amersham $^{\mathrm{TM}}$ Hyperfilm ${ }^{\mathrm{TM}}$ - were all purchased from ThermoFisher (Waltham, MA, USA). Western Lightning ${ }^{\circledR}$ 
Plus-ECL was from PerkinElmer (Waltham, MA, USA). Complete $^{\mathrm{TM}}$ protease inhibitor cocktail was from Roche (Basel, Switzerland). Primary antibodies targeting human $\mathrm{A} \beta$ : anti-A $\beta$ clone W0-2 (MABN10), anti-A $\beta_{40}$ clone $11 \mathrm{~A} 5-$ B10 (05-799), and anti-A $\beta_{42}$ clone $12 \mathrm{~F} 4$ (05-831-I) were from Merck (Kenilworth, MJ, USA). Anti-PS1 (D39D1) and anti-PS2 (D30G3) antibodies were from Cell Signaling (Danvers, MA, USA). Anti-APP-Cter (A8717) and anti- $\alpha-$ tubulin primary antibodies as well as secondary antibodies coupled to horseradish peroxidase (HRP) were obtained from Sigma-Aldrich (St-Louis, MO, USA). Alexa Fluor ${ }^{\mathrm{TM}}$ 647 secondary antibody was obtained from ThermoFisher. Thioflavin T (ThT) amyloid stain was obtained from SigmaAldrich. Mowiol ${ }^{\circledR}$ 4-88 used for mounting medium was purchased from Merck. Cell culture reagents-Ham's-F12, DMEM-F12, DMEM, and Neurobasal ${ }^{\circledR}$ growth media, penicillin-streptomycin (p-s) cocktail, Lipo2000® transfection reagent, Opti-MEM ${ }^{\circledR}$, HBSS, glutamine and B-27®—were all purchased from ThermoFisher. Fetal bovine serum (FBS) was from VWR (Radnor, PA, USA). GELFrEETM 8100 12\% Tris-Acetate cartridge kits were purchased from Expedeon (Heidelberg, Germany). ReadyProbes ${ }^{\circledR}$ cell viability assay kit was from ThermoFisher. ELISA strip plates for immunoEuropium assay (F8, high-binding 771261) were from Greiner Bio-One (Frickenhausen, Germany) and reagent diluent-2 10×(DY995) from R\&D systems (Minneapolis, MN, USA). Anti-CD9 primary antibody (MAB1880) was from R\&D systems, anti-CD81 (TAPA-1, 349502) from BioLegend (San Diego, CA, USA), anti-CD63 (MCA2142) from Serotec Bio-Rad (Kidlington, UK), and anti-GM130 (610823) from BD transduction (Franklin Lakes, NJ, USA). The anti-mouse IgG-biotin (NEF8232001EA), Europiumlabeled streptavidin (1244-360), Delfia ${ }^{\circledR}$ wash concentrate $25 \times(4010-0010)$, Delfia ${ }^{\circledR}$ assay buffer (1244-111), and Delfia ${ }^{\circledR}$ enhancement solution (1244-105) were all from PerkinElmer.

\section{DNA Constructs}

The pSVK3-empty (EP), -C42 and -C99 vectors used for expression in rodent cell lines (CHO, MEF) were described previously $[14,30]$. $\mathrm{C} 42$ and $\mathrm{C} 99$ are composed of the APP signal peptide fused to the human $\mathrm{A} \beta_{42}$ and $\beta C T F$ sequences, respectively. For the expression in human cell lines (HEK293, SH-SY5Y), the C99 construct in a pCDNA3.1 plasmid was kindly provided by R. Pardossi-Piquard (University of Sophia Antipolis, Nice, France). The pCDNA3.1 plasmid bearing the C99-GVP construct used in reporter gene assays was a gift from $\mathrm{H}$. Karlström (Karolinska Institute, Stockholm, Sweden). The associated Gal4RE-Firefly luciferase reporter gene (pG5E1B-luc) and Renilla luciferase reporter vector (pRL-TK) have been described previously $[21,31,32]$.

\section{Cell Lines Culture and Transfection}

Chinese hamster ovary $(\mathrm{CHO})$ cell lines were grown in Ham's-F12 medium; Human neuroblastoma SH-SY5Y cells and mouse embryonic fibroblasts (MEF) in DMEM-F12; Human embryonic kidney cells (HEK293 and HEK293-T) in DMEM. All media were supplemented with $10 \%$ of heatinactivated FBS and 100 units/ml p-s. All cell cultures were maintained at $37{ }^{\circ} \mathrm{C}$ in a humidified atmosphere and $5 \%$ $\mathrm{CO}_{2}$.

For transient transfection, 40,000 cells $/ \mathrm{cm}^{2}$ were seeded $24 \mathrm{~h}$ before transfection. Transfection mixes containing desired DNA and Lipo2000® were prepared in Opti-MEM $®$ and pre-incubated for $15 \mathrm{~min}$ at room temperature (rt). One day after transfection, medium was changed to fresh FBSfree culture medium and incubated for another $24 \mathrm{~h}$. Cell lysates and culture media were harvested $48 \mathrm{~h}$ after transfection for analysis.

\section{Western Blotting}

Cells were rinsed and scraped in phosphate-buffered saline (PBS) and centrifuged for $5 \mathrm{~min}$ at $7000 \times g$. Pellets were sonicated in lysis buffer (125 mM Tris pH 6.8, $20 \%$ glycerol, $4 \%$ SDS) with Complete ${ }^{\mathrm{TM}}$ protease inhibitor cocktail. Protein concentration was determined using the Pierce BCA protein assay kit. Proteins were heated for $10 \mathrm{~min}$ at $70{ }^{\circ} \mathrm{C}$ in loading buffer (lysis buffer supplemented with $50 \mathrm{mM}$ dithiothreitol (DTT) and NuPAGETM LDS sample buffer (ThermoFisher)). Samples were loaded and separated by SDS-PAGE electrophoresis on Nupage ${ }^{\mathrm{TM}} 4-12 \%$ Bis-Tris gels with MES SDS running buffer, using SeeBlue ${ }^{\mathrm{TM}}$ Plus2 pre-stained as a standard. Proteins were then transferred for $2 \mathrm{~h}$ at $30 \mathrm{~V}$ with NuPAGE ${ }^{\mathrm{TM}}$ transfer buffer onto $0.1 \mu \mathrm{m}$ nitrocellulose membranes. After blocking (5\% non-fat milk in PBS-Tween ${ }^{\circledR} 200.1 \%$ ), membranes were incubated overnight at $4{ }^{\circ} \mathrm{C}$ with the primary antibodies, then washed and incubated with the secondary antibodies coupled to HRP for $1 \mathrm{~h}$ prior to ECL detection. Primary antibodies were used as follows: anti-human A $\beta$ clone W0-2 (1:1500), anti-APPC-ter (1:2000), anti-PS1 (1:1000), anti-PS2 (1:1000), and anti- $\alpha$-tubulin (1:3000). Secondary antibodies were used as follows: HRP-coupled anti-mouse $\operatorname{IgG}(1: 10,000)$ or antirabbit $\operatorname{IgG}(1: 10,000)$.

\section{GELFrEE $^{\mathrm{TM}}$ Isolation of Cell-Derived Hexameric $A \boldsymbol{\beta}$}

$\mathrm{CHO}$ cells culture media were collected $48 \mathrm{~h}$ after transfection with either pSVK3-EP, -C42 or-C99, lyophilized, resuspended in ultrapure water and pre-cleared with recombinant protein $\mathrm{A}$ sepharose (GE Healthcare, Chicago, IL, USA). Immunoprecipitation of $A \beta$ species was performed with the monoclonal anti-human A $\beta$ clone W0-2 antibody. Samples were separated 


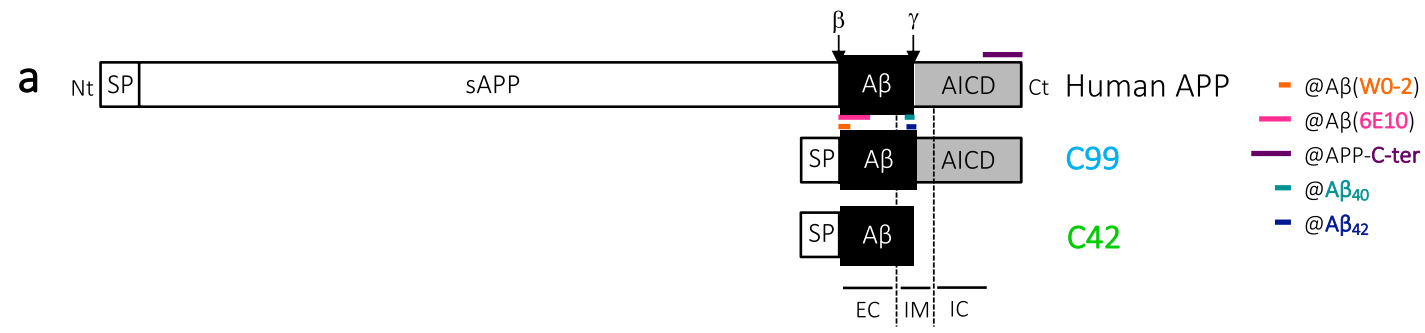

b
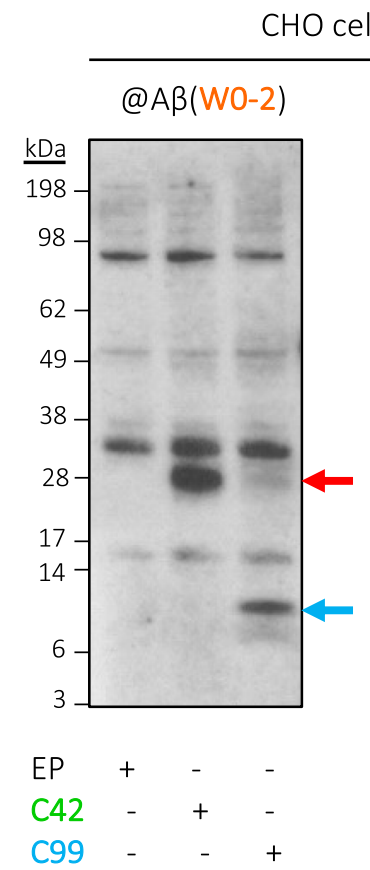

sates

@APP-C-ter

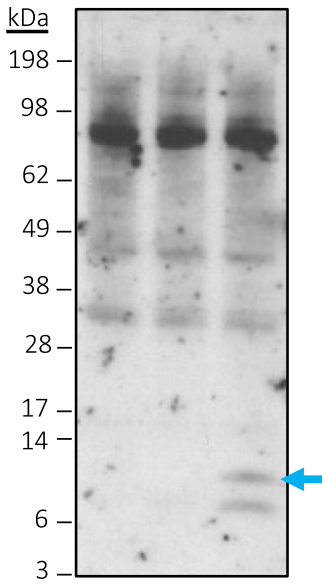

EP +

C42

C99
$\mathrm{CHO}$ culture media

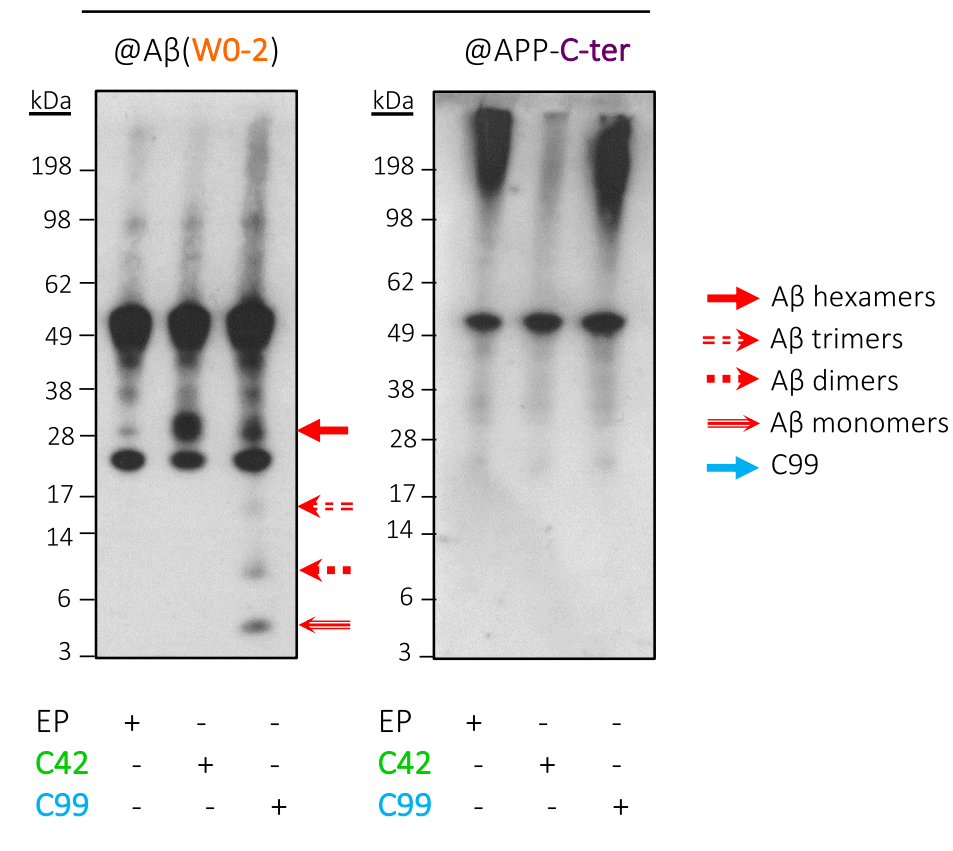

C GELFrEE ${ }^{\mathrm{TM}}$ on culture media @Aß(W0-2)

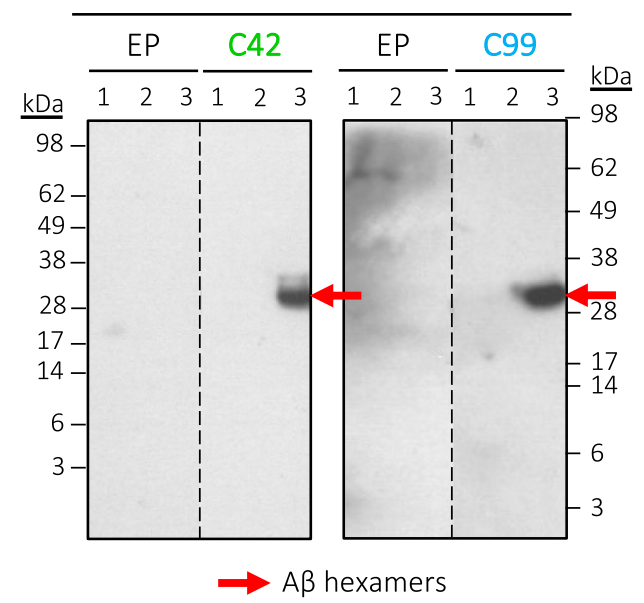

through a gel-eluted liquid fraction entrapment electrophoresis (GELFrEE ${ }^{\mathrm{TM}}$ 8100) system to allow the collection of the desired $\mathrm{kDa}$ range of proteins directly in liquid fraction. The following method was used for hexameric $A \beta$ collection: step
1: 60 min at $50 \mathrm{~V}$, step 2: 6 min at $70 \mathrm{~V}$, step 3: 13 min at $85 \mathrm{~V}$, and step 4: $38 \mathrm{~min}$ at $85 \mathrm{~V}$. Fractions 1, 2, and 3 (Fig. 1c) were collected at the end of steps 2, 3, and 4, respectively. All samples were collected in the system running buffer (1X buffer: 
4Fig. 1 Hexameric $\mathrm{A} \beta_{42}$ derived from $\mathrm{CHO}$ cells expressing human APP metabolites. a Full-length APP is cleaved by $\beta$-secretase at the $\beta$ site, located at the $\mathrm{N}$-terminus of $\mathrm{A} \beta$, to produce a 99 -amino acid membrane-bound fragment (C99) encompassing A $\beta$ and AICD. The C99 construct expressed here in the cells was fused to the signal peptide (SP) of APP. C99 is cleaved by $\gamma$-secretase to release A $\beta$. The C42 construct is composed of the SP of APP and the A $\beta_{42}$ sequence. The epitopes of the primary antibodies used in this study are indicated on the scheme; either directed against human $\mathrm{A} \beta$ (clones W0-2 and 6E10 targeting its $\mathrm{N}$-terminal part, and $\mathrm{A} \beta_{40}$ and $\mathrm{A} \beta_{42}$ antibodies specifically targeting the free $\mathrm{C}$-terminal end of $\mathrm{A} \beta$ ) or against the $\mathrm{C}$-terminal region of APP (APP-C-ter). $N t \mathrm{~N}$-terminus, $C t \mathrm{C}$-terminus, $s A P P$ soluble APP, AICD APP intracellular domain, $E C$ extracellular, $I M$ intramembrane, $I C$ intracellular. b Detection of $\sim 28 \mathrm{kDa}$ assemblies by Western blotting in $\mathrm{CHO}$ cell lysates and culture media following expression of either $\mathrm{C} 42$ or $\mathrm{C} 99$. These assemblies are recognized by $\mathrm{A} \beta$ specific antibodies (such as W0-2 here), but not by the anti-APP-C-ter, suggesting they emerge by assembly of A $\beta$. Media samples were lyophilized and all samples were immunoprecipitated with the anti-A $\beta$ (W0-2) antibody prior to analysis. In the media of C99-expressing cells, intermediate assemblies are also observed; monomers, dimers, and trimers. $E P$ empty plasmid. c Isolation of cell-derived A $\beta$ assemblies. The media of CHO cells expressing either EP, C42, or C99 were immunoprecipitated and separated using the GELFrEE ${ }^{\mathrm{TM}}$ technique. We optimized a method to collect the $\sim 28 \mathrm{kDa} \mathrm{A} \beta$ assemblies as an isolated liquid fraction. Dashed lines indicate that proteins were run on the same gel, but lanes are not contiguous

$1 \%$ HEPES, $0.01 \%$ EDTA, $0.1 \%$ SDS, and $0.1 \%$ Tris) and kept on ice. Absorbance at $280 \mathrm{~nm}$ of each fraction was read using a BioPhotometer® D30 (Eppendorf, Hamburg, Germany) and the concentration of the collected hexameric $A \beta$ was calculated using the molar extinction coefficient $\varepsilon_{280 \mathrm{~nm}}=1490 \mathrm{M}^{-1} \mathrm{~cm}^{-1}$.

\section{Dot Blotting}

$5 \mu \mathrm{l}$ of isolated hexameric $\mathrm{A} \beta(150 \mu \mathrm{M}$ for isoform characterization, $15 \mu \mathrm{M}$ for fractions evaluation prior to intracerebral injection) and $5 \mu \mathrm{l}$ of $50 \mu \mathrm{M}$ synthetic monomeric $\mathrm{A} \beta(\mathrm{mA} \beta)$ with $40\left(\mathrm{~mA} \beta_{40}\right)$ or 42 residues $\left(\mathrm{mA} \beta_{42}\right)$ were spotted onto $0.1 \mu \mathrm{m}$ nitrocellulose membranes and allowed to dry. Another $5 \mu \mathrm{l}$ of sample were then spotted twice on top and dried. The membranes were boiled twice in PBS for 3 min, then blocked with 5\% non-fat milk in PBS-Tween ${ }^{2} 20$ $0.1 \%$, washed and incubated with primary and secondary antibodies prior to ECL detection, as described above. Primary antibodies dilutions were used as follows: anti-human A $\beta$ clone W0-2 (1:1500), anti-A $\beta_{40}(1: 1000)$, and anti-A $\beta_{42}$ (1:1000). Secondary antibodies were used as described for Western blotting. Synthetic $\mathrm{mA} \beta_{40}$ and $\mathrm{mA} \beta_{42}$ were prepared as previously described [33].

\section{Generation of SH-SY5Y PS1- and PS2-Deficient Cells by CRISPR-Cas9}

Kits each containing guide RNA vectors that target human PSEN1 or PSEN2 genes, a GFP-puromycin or
RFP-blasticidin donor vector, respectively, and a scrambled sequence control were obtained from Origene (CAT\#: KN216443 and KN202921RB). Target sequences were flanked with specific homology sequences for the stable integration of donor sequences, based on the homologydirected repair technique [34, 35]. SH-SY5Y cells were transfected using Lipo2000® and FACS-sorted $48 \mathrm{~h}$ later for GFP + (PS1) or RFP + (PS2) cells, then seeded in $24 \mathrm{w}$ plates. Following a few days for cell-growth, a second selection was performed using puromycin (PS1) or blasticidin (PS2) at a concentration of $15 \mu \mathrm{g} / \mathrm{ml}$ or $30 \mu \mathrm{g} / \mathrm{ml}$, respectively. Cells were then allowed to grow again and split twice before subcloning in 96w plates. PS 1 and PS 2 clonal populations were selected for following experiments on account of the highest gene-extinction efficiency, mirrored by the strongest decrease in protein levels. Puromycin $(2.5 \mu \mathrm{g} / \mathrm{ml})$ and blasticidin $(7.5 \mu \mathrm{g} / \mathrm{ml})$ were used for the maintenance of PS1 - and PS2-deficient cells, respectively.

\section{Dual Luciferase Assay}

SH-SY5Y cells were co-transfected with Lipo2000® in a 1:1:1 ratio with pG5E1B-luc, pRL-TK, and either a pCDNA3.1-empty plasmid (EP) or the pCDNA3.1-C99GVP, bearing a tagged C99 to quantify the release of the APP intracellular domain (AICD). The system setup was previously described [21, 32]. Cells were rinsed with PBS $48 \mathrm{~h}$ after transfection and incubated with the reporter lysis buffer (Promega, Madison, WI, USA) for $15 \mathrm{~min}$ at rt. Firefly and Renilla luciferase activities were measured using the Dual-Glo® luciferase assay system (Promega, Madison, WI, USA) on a Sirius single tube luminometer (Berthold, Bad Wildbad, Germany). Luciferase activity corrected for transfection efficiency was calculated as the Firefly/Renilla ratio.

\section{Electro-Chemiluminescence Immunoassay (ECLIA) for Monomeric A $\beta$ Quantification}

$\mathrm{A} \beta$ monomeric peptides were quantified in human CSF or in SH-SY5Y cells media using the human A $\beta 6 \mathrm{E} 10$ multiplex ECLIA assay (Meso Scale Discovery, Gaithersburg, MD, USA) as previously described [36]. For SH-SY5Y, cells were conditioned in FBS-free medium for $24 \mathrm{~h}$. After collection, medium was lyophilized and resuspended in ultrapure water prior to analysis.

\section{Extracellular Vesicles Isolation}

Culture medium was collected and underwent several centrifugation steps (all at $4{ }^{\circ} \mathrm{C}$ ): $300 \times g$ for $10 \mathrm{~min}$ for the elimination of living cells, $1000 \times g$ for $10 \mathrm{~min}$ to discard dead cells, $10,000 \times g$ for $30 \mathrm{~min}$ for the removal of cellular debris, and finally $100,000 \times g$ for $1 \mathrm{~h}$ to collect extracellular vesicles 
(EVs) as a pellet and soluble proteins as supernatant. Soluble proteins were precipitated by incubation with $10 \%$ trichloroacetic acid (TCA) for 30 min on ice. Both EVs and soluble proteins fractions were resuspended in $500 \mu \mathrm{l}$ of PBS for nanoparticle tracking analysis (NTA) and plate-based Europium-immunoassay. For Western blotting, a saved portion of both fractions was sonicated in lysis buffer (125 mM Tris pH 6.8, 20\% glycerol, 4\% SDS) with Complete ${ }^{\mathrm{TM}}$ protease inhibitor cocktail. Protein concentration was determined using the Pierce BCA protein assay kit.

\section{Nanoparticle Tracking Analysis (NTA)}

EVs were counted in each fraction by the ZetaView ${ }^{\circledR}($ ParticleMetrix GmbH, Inning am Ammersee, Germany), which captures Brownian motion through a laser scattering microscope combined with a video camera to obtain size distribution (50-1000 nm) and concentration. Samples were diluted 1:50 (v:v) in PBS to reach 50-200 particles/frame, corresponding to $\sim 2 \times 10^{7}-1 \times 10^{8}$ particles $/ \mathrm{ml}$. Sensitivity was set to 65 and camera shutter to 100 in order to detect less than 3 particles/frame when PBS alone was injected, to assess background signal. Measurements were averaged from particles counted in 11 different positions for 2 repeated cycles with camera at medium resolution mode.

\section{Plate-Based Europium-Immunoassay}

$50 \mu \mathrm{l}$ of EVs and soluble proteins fractions were bound to protein-binding ELISA plates. After overnight incubation at $4{ }^{\circ} \mathrm{C}$, the rest of the experiment was performed at $\mathrm{rt}$ by shaking on a tilting shaker at $30 \mathrm{rpm}$. The plate was washed with Delfia ${ }^{\circledR}$ buffer (diluted to $1 \times$ in PBS: Delfia ${ }^{\circledR}-W$ ), then blocked with reagent diluent-2 (diluted to $1 \%$ BSA in PBS) for $90 \mathrm{~min}$. The bound material was labeled with primary antibodies against CD9, CD81, CD63, and GM130 (1 $\mu \mathrm{g} /$ $\mathrm{ml}$ in reagent diluent-2) for $90 \mathrm{~min}$. After three Delfia ${ }^{\circledR}-\mathrm{W}$ washes, goat anti-mouse biotinylated antibody (1:2500 in reagent diluent-2) was added for $60 \mathrm{~min}$. After another three Delfia ${ }^{\circledR}-W$ washes, Europium-conjugated streptavidin (diluted to 1:1000 in Delfia ${ }^{\circledR}$ buffer) was added for 45 min. After six final Delfia ${ }^{\circledR}-W$ washes, Delfia ${ }^{\circledR}$ enhancement solution was incubated for $15 \mathrm{~min}$ before measurement using time-resolved fluorometry with excitation/emission: $340 / 615 \mathrm{~nm}$, flash energy/light exposure: high/medium, and integration lag/counting time: 400/400 $\mu$ s (VICTOR $®$ X4 multilabel plate reader, PerkinElmer).

\section{Generation of SH-SY5Y PS2 Rescued Cells}

Wild-type human PS2 (hPS2) generated in a previously described plasmid vector [37] was subcloned in the pLentiCMV/TO-puro lentiviral vector (plasmid 17482, Addgene).
Lentiviruses production was carried out in HEK293-T cells. $48 \mathrm{~h}$ after transfection with the hPS2 vector, cells were harvested and centrifuged at $1500 \times g$ for $10 \mathrm{~min}$ at $4{ }^{\circ} \mathrm{C}$. The supernatant was filtered with an Acrodisc ${ }^{\circledR} 0.45 \mu \mathrm{m}$ filter (Pall, NYC, USA). Then, 1/3 (v/v) of LentiX ${ }^{\mathrm{TM}}$ Concentrator reagent (Clontech, Mountain View, USA) was added and the solution was incubated overnight. After centrifugation at $1500 \times \mathrm{g}$ for $45 \mathrm{~min}$ at $4{ }^{\circ} \mathrm{C}$, the pellet was resuspended in $20 \mu \mathrm{l}$ per dish of DMEM without serum and stored at $-80^{\circ} \mathrm{C}$ until use. $80 \mu \mathrm{l}$ of concentrated viruses were used to infect $3 \times 10^{6} \mathrm{SH}-\mathrm{SY} 5 \mathrm{Y}$ PS2-KD cells. Selection started $72 \mathrm{~h}$ after infection by adding $5 \mu \mathrm{g} / \mathrm{ml}$ puromycin. Recombinant cell lines were further cultivated in culture medium containing $2.5 \mu \mathrm{g} / \mathrm{ml}$ puromycin, and the PS2 expression profile was monitored by Western blotting.

\section{Animal Models}

Transgenic 5xFAD mice (Tg6799) harboring human APP and PSEN1 transgenes were originally obtained from the Jackson Laboratory: B6SJL-Tg(APPSwFlLon,PSEN1*M 146L*L286V)6799Vas/Mmjax (34840-JAX). Colonies of $5 \mathrm{xFAD}$ and non-transgenic (wild-type, WT) mice were generated from breeding pairs kindly provided by Pr. JeanPierre Brion (ULB, Brussels, Belgium). All mice were kept in the original C57BL/6 background strain. Animals were housed with a $12 \mathrm{~h}$ light/dark cycle and were given ad libitum access to food and water. All experiments conducted on animals were performed in compliance with protocols approved by the UCLouvain Ethical Committee for Animal Welfare (reference 2018/UCL/MD/011).

\section{Protein Extraction from Mouse Brain Tissues}

WT and 5xFAD mice of either sex were euthanized by cervical dislocation or using $\mathrm{CO}_{2}$, and brains were quickly removed. The hippocampus and a portion of temporal cortex were immediately dissected on ice. Brain tissues were then homogenized by pipetting up and down with a $1000 \mu \mathrm{l}$ pipette and sonicating in ice-cold lysis buffer $(150 \mathrm{mM}$ $\mathrm{NaCl}, 20 \mathrm{mM}$ Tris, 1\% NP40, 10\% glycerol) with Complete $^{\mathrm{TM}}$ protease inhibitor cocktail until homogenous. Samples were stored at $-80{ }^{\circ} \mathrm{C}$ until use. Protein concentration was determined using the Pierce BCA protein assay kit prior to analysis.

\section{Cerebrospinal Fluid Collection}

Cerebrospinal fluid (CSF) was collected by lumbar puncture from $\mathrm{AD}$ patients and symptomatic controls undergoing diagnostic work-up at the Cliniques Universitaires Saint-Luc (UCL, Brussels, Belgium), both of either sex, following the international guidelines for CSF biomarker research [38]. 
Collected samples were directly frozen at $-80{ }^{\circ} \mathrm{C}$ until analysis and were always manipulated on ice during Western blotting and ECLIA experiments. Included patients signed an internal regulatory document, stating that residual samples used for diagnostic procedures can be used for retrospective academic studies, without any additional informed consent (ethics committee approval: 2007/10SEP/233). AD patients participated in a specific study referenced UCL2016-121 (Eudra-CT: 2018-003473-94). In total, CSF samples from eight subjects were retrospectively monitored in this study (see Supplementary Table.S1).

\section{Intracerebral Stereotaxic Surgery}

2-month-old WT and 5xFAD mice of either sex were deeply anesthetized by intraperitoneal injection of a mixture of ketamine (Ketamin $®)(10 \mathrm{mg} / \mathrm{kg})$ and medetomidine (Domitor®) $(0.5 \mathrm{mg} / \mathrm{kg})$, and placed in a stereotaxic apparatus (Kopf ${ }^{\circledR}$ Instruments, Tujunga, CA, USA). $2 \mu 1$ of $15 \mu \mathrm{M}$ cell-derived hexameric $A \beta$ (C42 fraction) or control (EP fraction) were injected using a $10 \mu 1$ Hamilton syringe and an automated pump (RWD®, Guangdong, China). Coordinates used for intrahippocampal injection were based on the Paxinos atlas: A/P $-1.94 ; \mathrm{L} \pm 2.17 ; \mathrm{D} / \mathrm{V}-1.96 ; \mathrm{mm}$ relative to bregma, considering a bregma-lambda distance of $4.21 \mathrm{~mm}$. When the distance differed, coordinates were proportionally adjusted. 30 days after stereotaxic injection, mice were transcardially perfused with PBS and brains were post-fixed in $4 \%$ paraformaldehyde for $24 \mathrm{~h}$ at $4{ }^{\circ} \mathrm{C}$.

\section{Immunohistofluorescence}

For immunohistological analysis, free-floating coronal sections $(50 \mu \mathrm{m})$ were generated from agarose-embedded fixed brains using a vibrating HM650V microtome (ThermoFisher), and were preserved in PBS-sodium azide 0.02\% at $4{ }^{\circ} \mathrm{C}$. Prior to immunomarking, sections were washed in PBS and subsequently blocked and permeabilized with PBSBSA 3\%-TritonX100 $0.5 \%$ for $1 \mathrm{~h}$ at rt. Sections were then incubated with anti-human A $\beta$ clone W0-2 (1:100) overnight at $4{ }^{\circ} \mathrm{C}$ as a marker for $\mathrm{A} \beta$-containing species. After three PBS washes and incubation with goat anti-mouse IgG Alexa Fluor $^{\mathrm{TM}} 647$ secondary antibody (1:500) for $1 \mathrm{~h}$ at $\mathrm{rt}$, slices were finally washed three times with PBS and mounted on SuperFrost ${ }^{\circledR}$ slides. Slides were then incubated with ThT $(0.1 \mathrm{mg} / \mathrm{ml}$ in ethanol $50 \%)$ for $15 \mathrm{~min}$ at $\mathrm{rt}$ as a marker for fibrillar deposits. After three washes with ethanol $80 \%$ and a final wash with ultrapure water, coverslips were mounted with Mowiol ${ }^{\circledR}$ 4-88-glycerol. W0-2 and ThT staining were detected with standard FITC/Cy5 and GFP filters, respectively, at an EVOS ${ }^{\circledR}$ FL Autofluorescence microscope. Counting of double-positive dots was performed on ImageJ.

\section{Primary Neuronal Cultures}

Primary cultures of neurons were performed on mouse embryos of either sex at embryonic day 17 (E17), as described previously [39]. Briefly, cortices and hippocampi were isolated by dissection on ice-cold HBSS and meninges were removed. Tissues were then dissociated by pipetting up and down 15 times with a glass pipette. Dissociation was repeated 10 times with a flame-narrowed glass pipette and samples were allowed to sediment for $5 \mathrm{~min}$. Supernatants containing isolated neurons were then settled on $4 \mathrm{ml}$ FBS and centrifuged at $1000 \times g$ for $10 \mathrm{~min}$. Pellets were resuspended in Neurobasal $®$ medium enriched with $1 \mathrm{mM}$ L-glutamine and 2\% B-27® supplement medium. 100,000cells/ $\mathrm{cm}^{2}$ were plated in $12 \mathrm{w}$ plates pre-coated with poly-L-lysine (Sigma-Aldrich). Cultures were maintained at $37{ }^{\circ} \mathrm{C}$ and $5 \%$ $\mathrm{CO}_{2}$ in a humidified atmosphere.

\section{Cell Viability Assay (ReadyProbes ${ }^{\circledR}$ )}

Primary neuronal cultures performed from WT and 5xFAD mouse embryos of either sex were incubated at 7 days in vitro (DIV7) with 1 or $5 \mu \mathrm{M}$ of either cell-derived hexameric $\mathrm{A} \beta$ (C42 fraction) or control (EP fraction). At DIV8, 2 drops $/ \mathrm{ml}$ of each reagent of the ReadyProbes ${ }^{\circledR}$ assay were added to cells: NucBlue ${ }^{\circledR}$ Live reagent for the staining of all nuclei and NucGreen ${ }^{\circledR}$ Dead reagent for the nuclei of cells with compromised plasma membrane integrity. Staining were detected with standard DAPI and FITC/GFP filters, respectively, at an EVOS $®$ FL Autofluorescence microscope. Quantification was performed by counting dead vs total cells on ImageJ.

\section{Statistical Analyses}

The number of experiments $(N)$ and the number of samples per condition in each experiment $(n)$ are indicated in figure legends. All statistical analyses were performed using the GraphPad Prism 8 software (GraphPad Software, La Jolla, CA, USA). All datasets were assessed for gaussian distribution using the Shapiro-Wilk test. A parametric test was applied if the data followed normal distribution. Otherwise, non-parametric tests were used. Statistical analysis performed in each case is indicated in the corresponding figure legend. Briefly, when tested groups were expressed as a fold-change of their corresponding control, the value of the control was set as the hypothetical value for the use of parametric one-sample $t$ test or non-parametric onesample Wilcoxon single-ranked test. When a correlation between two variables was assessed, Pearson's $R$ correlation coefficient was calculated. When two groups were compared, parametric $t$ or non-parametric Mann-Whitney tests were used. When more than two groups were compared, 
a

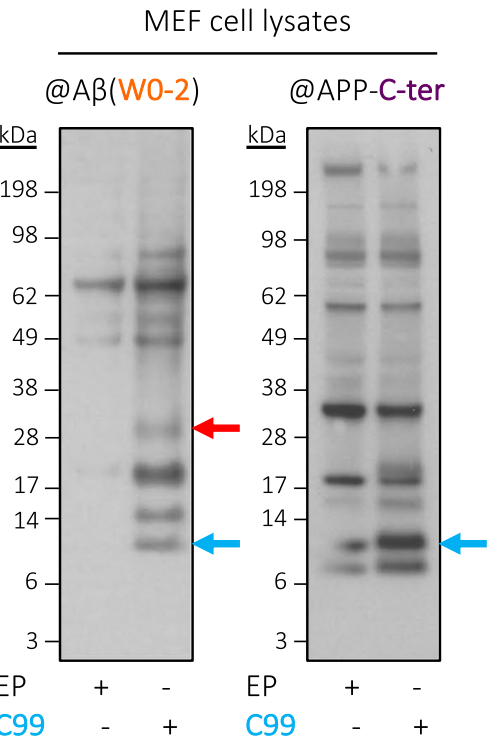

b

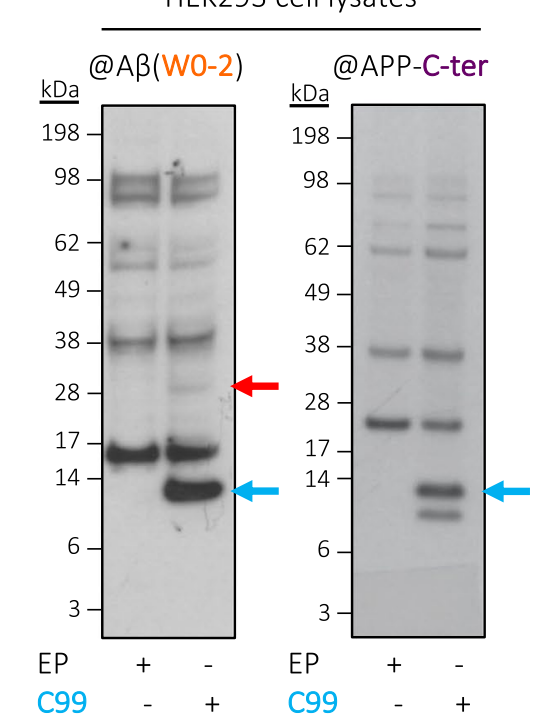

C

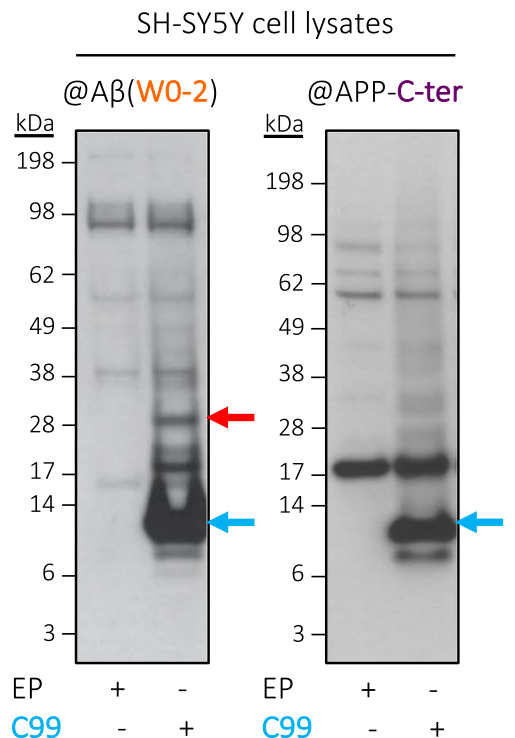

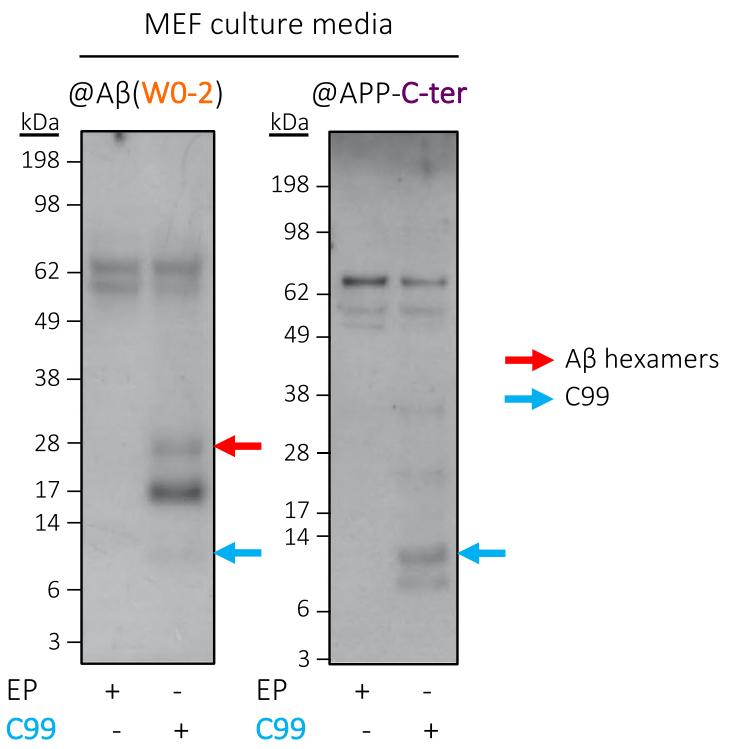
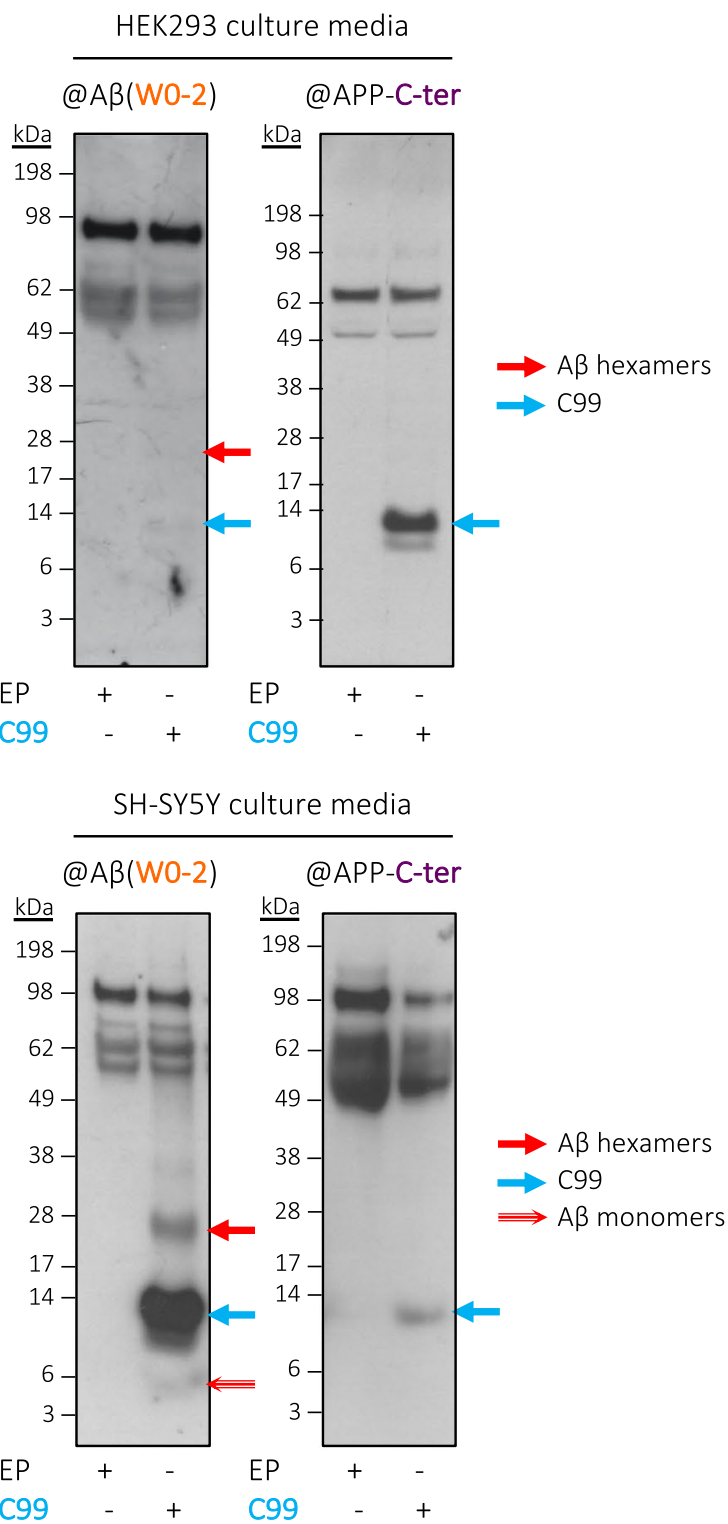
4Fig. 2 Commonality of hexameric $\mathrm{A} \beta$ production in several cell lines. Cell lysates and media from murine MEF fibroblasts (in a) and human embryonic HEK293 cells (in b), as well as from human neuroblastomaderived SH-SY5Y cells (in c) expressing C99 all revealed the presence of $\sim 28 \mathrm{kDa}$ assemblies recognized by the human $\mathrm{A} \beta$-specific W0-2 antibody, and not by the anti-APP-C-ter. Media samples were lyophilized prior to analysis. $E P$ empty plasmid

parametric ANOVA with indicated post hoc tests or nonparametric Kruskal-Wallis were used. Significance is indicated as follows: ns $=$ non-significant, ${ }^{*} p<0.05,{ }^{* *} p<0.01$, $* * * p<0.001$. Actual $p$-values of each test are indicated in the corresponding figure legend.

\section{Results}

\section{Identification of Hexameric $A \beta_{42}$ Assemblies Across a Wide Range of Cell Lines}

The growing body of evidence pointing to the pathological properties of oligomeric — and particularly hexameric - $\mathrm{A} \beta$ assemblies mostly stems from observations gathered using synthetic $A \beta$ peptides. We focused on the identification of $\mathrm{A} \beta$ assemblies that are readily formed in a cellular context. These studies were first carried out in CHO (Chinese hamster ovary) cells transiently transfected with vectors expressing the human sequences of either $A \beta_{42}$ (referred to as $\mathrm{C} 42$ ) or $\beta \mathrm{CTF}$ (C99), each fused to the APP signal peptide to ensure a proper cellular trafficking of the expressed fragments (Fig. 1a). The $A \beta$ assemblies formed in this cellular context were analyzed by Western blotting (Fig. 1b) using a combination of antibodies, targeting epitopes present in either the human $A \beta$ sequence (W0-2 and $6 \mathrm{E} 10$ ) or in the APP C-terminal region (APP-C-ter) (Fig. 1a). As previously reported $[14,15]$, we repeatedly detected a band at $\sim 28 \mathrm{kDa}$ in both $\mathrm{C} 42$ and $\mathrm{C} 99$-expressing cells with $\mathrm{A} \beta$-specific antibodies (W0-2 in Fig. 1b and 6E10 in Supplementary Fig.S1). These assemblies were not recognized by the antiAPP-C-ter specific antibody (Fig. 1b), indicating that they are formed by self-association of the $A \beta$ fragment and do not correspond to the previously reported C99 dimers [30, 40]. Their observed size corresponds to the theoretical size of hexameric $A \beta$. In addition, intermediate $A \beta$ assemblieslikely corresponding to monomers, dimers and trimers of $\mathrm{A} \beta$ - were detected in the media of C99-expressing cells. As the cleavage of C99 in a cell generates various forms of $\mathrm{A} \beta$ and mostly $A \beta_{40}$, this suggests that assemblies smaller than hexamers are formed when such various forms of $A \beta$ are produced upon $\mathrm{C} 99$ processing, but that hexameric forms are predominant when only $\mathrm{A} \beta_{42}$ is produced by cells, as is the case for C42-expressing cells.

For a further characterization of the identified $A \beta$ assemblies, we used a gel-eluted liquid fraction entrapment electrophoresis technique (GELFrEE $\left.{ }^{\mathrm{TM}} 8100\right)$ to isolate the cell-derived $\mathrm{A} \beta$ assemblies from W0-2-immunoprecipitated media of $\mathrm{C} 42$ or C99-expressing $\mathrm{CHO}$ cells (Fig. 1c). This technique was recently used for extensive biochemical analyses of oligomeric A $\beta$ produced by cells [15]. Dot blotting with primary antibodies directed against the free $\mathrm{C}$-terminal end of the two major $A \beta$ isoforms $\left(A \beta_{40}, A \beta_{42}\right)$ was performed on the isolated $\sim 28 \mathrm{kDa}$ assemblies. It indicated they were composed of $A \beta_{42}$ (see Supplementary Fig.S2 and [15]). Thus, the $A \beta$ assemblies we identified in a cellular context likely correspond to hexameric $\mathrm{A} \beta_{42}$ assemblies.

As $A \beta$ self-assembly strongly depends on the context of its release, we sought to determine whether the assemblies of interest were produced specifically by $\mathrm{CHO}$ cells or more generally across various cell lines. Using the same procedure as described above [15], we assessed the $A \beta$ profile in transiently transfected mouse embryonic fibroblasts (MEF) (Fig. 2a) as well as in two human cell lines: human embryonic kidney (HEK293) cells (Fig. 2b) and neuroblastoma-derived SH-SY5Y cells (Fig. 2c). Importantly, the $\sim 28 \mathrm{kDa}$ assemblies were consistently detected with the W0-2 A $\beta$-specific antibody and not by the APP-Cter-targeted antibody in all the tested models (Fig. 2). The amounts of $\sim 28 \mathrm{kDa} A \beta$ assemblies produced by the different cell lines are variable and notably lower in HEK293, but our results indicate that similar, hexameric-like $A \beta$ assemblies can readily form across different cell lines and are not restricted to one cell-type, fostering their relevance as a critical cell-derived $\mathrm{A} \beta$ assembly.

\section{Cellular Pathways and Contribution of Presenilins to the Formation of Hexameric-Like A $\beta$ Assemblies}

We next aimed at understanding the cellular context in which hexameric-like $A \beta$ is formed. In a cell, the production of any $A \beta$ species requires the catalytic processing of the $\mathrm{C} 99$ fragment by the $\gamma$-secretase complex, a step that is ensured either by presenilin-1 (PS1) or presenilin-2 (PS2). Previous studies demonstrated that PS1- and PS2-dependent $\gamma$-secretases have differential substrate specificities [21, 41] and that several factors, including their specific subcellular localization [23], can promote the production of longer and more aggregation-prone $A \beta$ isoforms. Thus, we investigated the contribution of PS1- and PS2-dependent $\gamma$-secretases to the formation of $\mathrm{A} \beta$ species that would be capable of assembling into hexameric-like $A \beta$.

For this, we evaluated the profile of $A \beta$ species formed in human cells expressing the $\mathrm{C} 99$ fragment and lacking either PS1 or PS2. We used a CRISPR-Cas9 editing approach $[34,35]$ to generate PS1 and PS2 knockdown (KD) neuron-derived human cell lines (SH-SY5Y cells). SH-SY5Y cells readily produced hexameric-like $A \beta$ assemblies in our conditions (Fig. 2c). Cells were stably transfected with a 
a
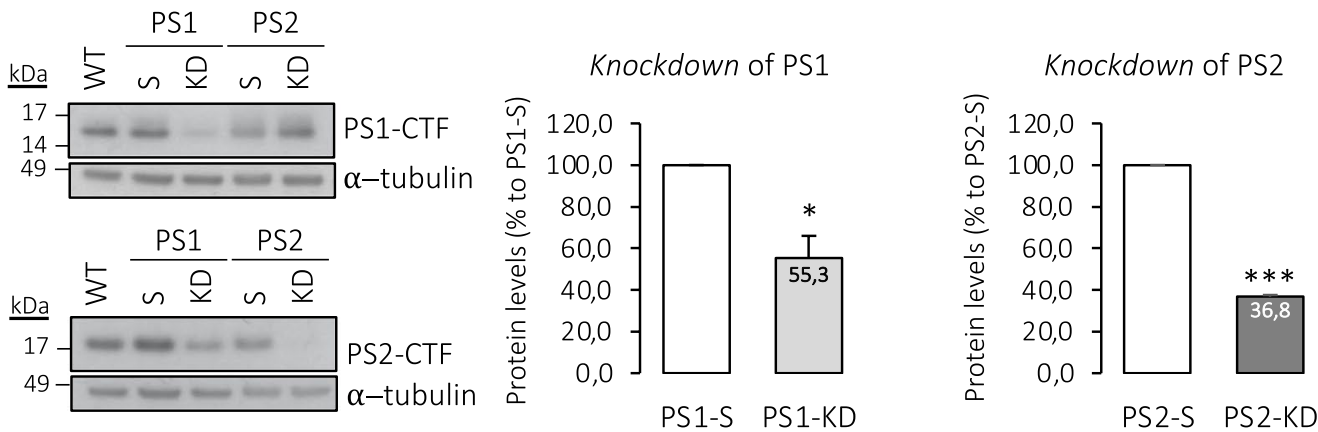

b

Cell lysates

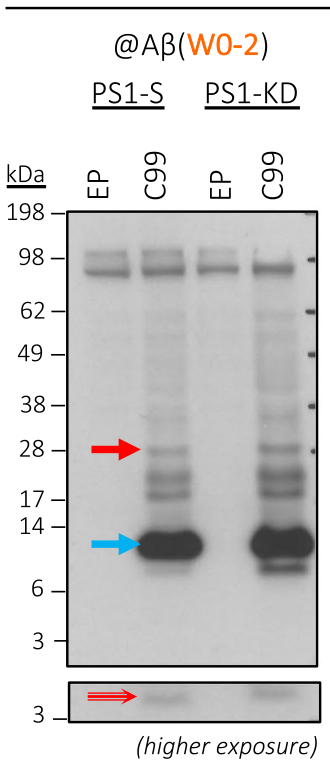

Initial cleavage of C99

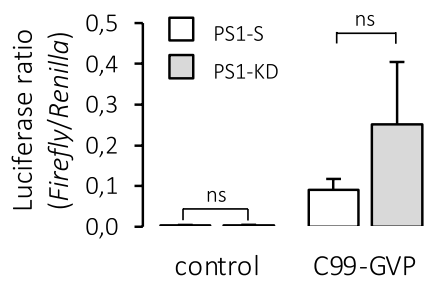

Hexameric $A \beta$ in cell lysates
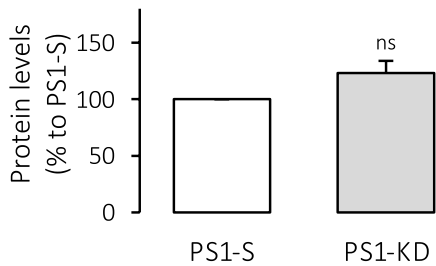

C

Cell lysates

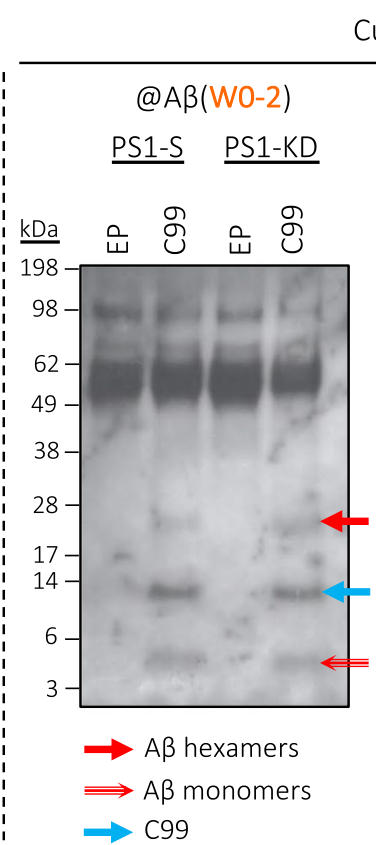

Culture media
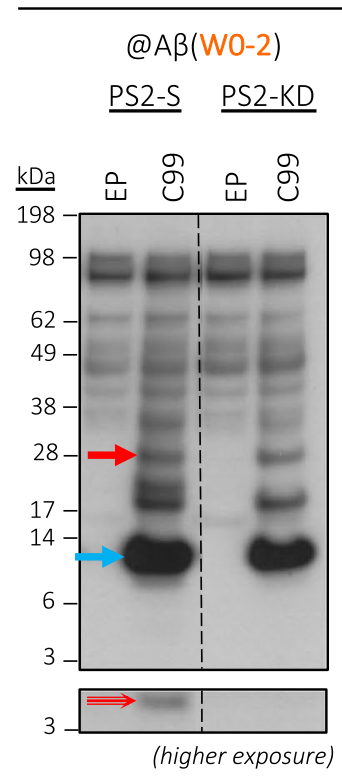

Initial cleavage of C99

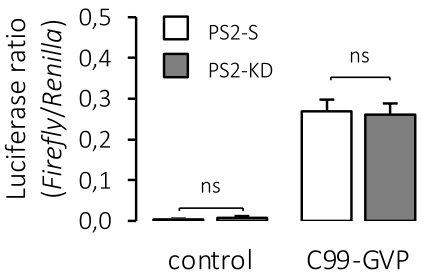

Hexameric $A \beta$ in cell lysates
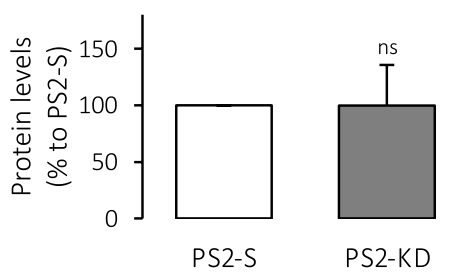

Culture media

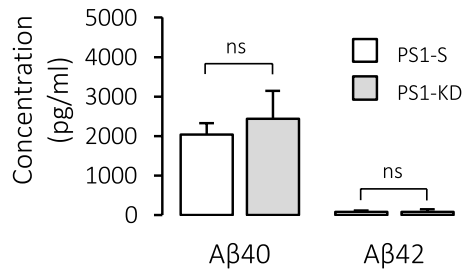

Hexameric $A \beta$ released
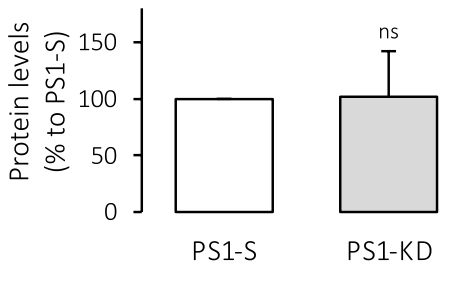

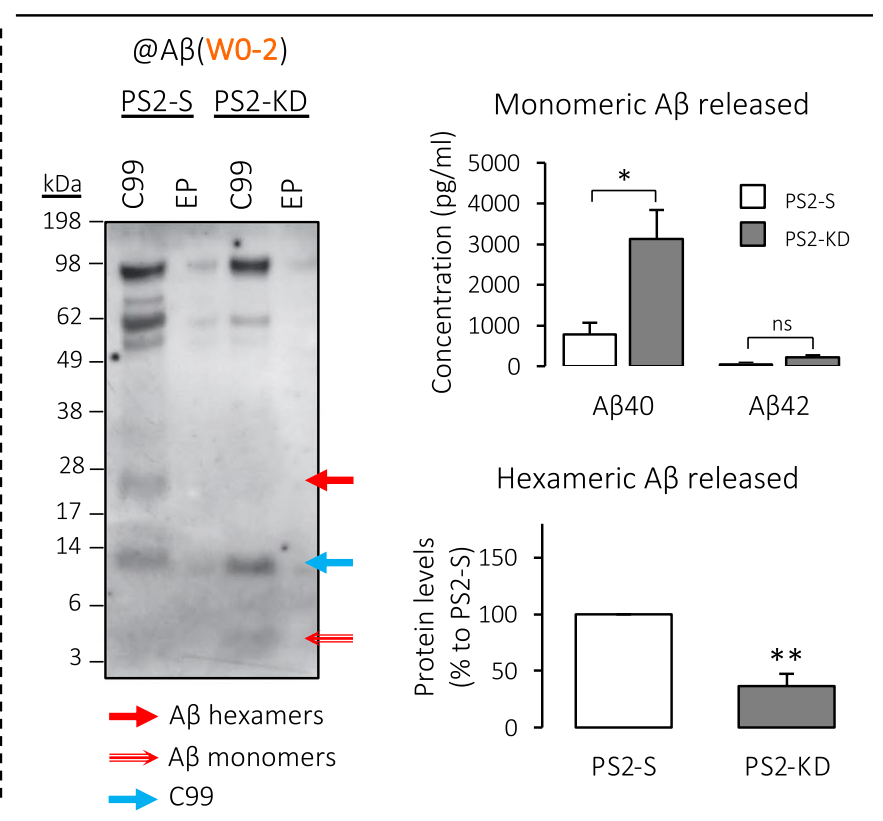


4 Fig. 3 Contribution of presenilins to the production of hexameric A $\beta$ assemblies. a SH-SY5Y knockdown (KD) cell lines were generated using CRISPR-Cas9, with guide RNA vectors targeting either human PSEN1 (PS1-KD) or PSEN2 (PS2-KD) genes. Control cells were transfected with respective scrambled sequences. Left, a representative Western blot; middle and right, quantitative decrease in PS1 and PS2 protein levels in KD compared to $\mathrm{S}$ cells (for all conditions, see Supplementary Fig.S2). $N=3$. One-sample $t$ test with hypothetical value set as 100: $* p<0.05, * * * p<0.001$ (S vs KD, in PS1: $p=0.03$; in PS2: $p=0.0001)$. $W T$ wild-type, $S$ scrambled. b, c Initial cleavage ability was monitored by a reporter gene assay. The release of APP intracellular domain (AICD) from a tagged C99-GVP substrate was measured by the Gal4-Firefly reporter gene. Results are represented as Firefly/Renilla luciferases ratios, with Renilla serving as a transfection-efficiency control. The profile of $\mathrm{A} \beta$ production was assessed after transfection with either an empty plasmid (EP) or C99, using Western blotting and ECLIA immunoassay, in PS1-KD vs PS1-S (in b) and in PS2-KD vs PS2-S (in c). Media samples were lyophilized prior to analysis. Dashed lines indicate that proteins were run on the same gel, but lanes are not contiguous. Luciferase assays (initial cleavage of C99): $N=4$ each. One-way ANOVA with Tukey's multiple comparison test: $\mathrm{ns}=$ non-significant $(\mathrm{S}$ vs $\mathrm{KD}$, in PS1 control: $p>0.99$; in PS1 C99-GVP: $p=0.10$; in PS2 control: $p=0.99$; in PS2 C99-GVP: $p=0.99$ ). Western blots quantitative analyses (hexameric $\mathrm{A} \beta$, in cell lysates and released, relative to $\mathrm{C} 99$ and expressed as a \% to $\mathrm{S}$ ): $N=3$ each. One-sample $t$ test with hypothetical value set as 1 : $n s$ non-significant, ${ }^{*} p<0.01$ (S vs KD, in PS1 cell lysates: $p=0.16$; in PS1 media: $p=0.97$; in PS2 cell lysates: $p=0.99$; in PS2 media: $p=0.01$ ). ECLIA assays (monomeric A $\beta$ released): $N=5$ each. Mann-Whitney test: $n s$ non-significant, ${ }^{*} p<0.05$ (S vs KD, in PS1 $\mathrm{A} \beta_{40}: p>0.99$; in PS1 $\mathrm{A} \beta_{42}: p>0.99$; in PS2 $\mathrm{A} \beta_{40}: p=0.04$; in PS2 $\mathrm{A} \beta_{42}: p=0.12$ )

CRISPR-Cas9 expression system targeting either PSEN1 or PSEN2 genes, and selected using fluorescent (FACS) and antibiotic resistance double-selections. Scrambled (S) target sequences for both the PSEN1 and PSEN2 genes were used for the generation of control cell lines. After subcloning, the expression of both presenilins (PSs) was verified by Western blotting (Fig. 3a) which showed a $44.7 \%$ and $63.2 \%$ reduction of PS1 and PS2 protein levels, respectively. To note, the levels of the other-non-targeted-PS was not significantly affected (Supplementary Fig.S3).

We first assessed the ability of the KD cells to perform the initial cleavage of the C99 substrate, releasing the APP intracellular domain (AICD). The AICD release from a tagged C99-GVP substrate was measured by a Gal4 reporter gene assay, as described previously [21, 32]. Results revealed an efficient cleavage of the C99-GVP construct in both the PS1-KD and PS2-KD cells, when compared to PS1-S and PS2-S controls, respectively. This suggests that neither the PS1 nor PS2 knockdown blocked the processing at the initial $\gamma$-secretase cleavage site. We next investigated the profile of $\mathrm{A} \beta$ production in these cell lines by combining Western blotting and ECLIA techniques. Results indicated that the reduction in PS1 levels had no significant effect on the profile of $A \beta$ present inside or outside of the cell (Fig. 3b), with no significant decrease in monomeric $A \beta$ measured in culture media. This was quite an unexpected observation that could be explained by the fact that only around $50 \%$ of PS1 knockdown was achieved in our model. The remaining PS1-dependent $\gamma$-secretase activity could be sufficient to efficiently process APP-derived substrates. However, while the formation of intracellular hexameric $\mathrm{A} \beta$ was similar between PS2-KD and corresponding control cells, intracellular monomeric A $\beta$ was no longer detectable when PS2 expression was reduced. Concomitantly, the extracellular $\mathrm{A} \beta$ assembly profile was altered in PS2-KD cells, with an increase in monomeric form and an acute decrease in hexameric $A \beta$, suggesting that the extracellular release of the hexameric-like $A \beta$ assemblies is dependent on the presence of PS2 (Fig. 3c). This would illustrate that the absence of PS2 (i) favors the accumulation of monomeric extracellular $\mathrm{A} \beta$ and (ii) leads to decreased intracellular monomeric $\mathrm{A} \beta$ and decreased extracellular aggregates. In other words, PS2dependent $\gamma$-secretases could generate aggregation-prone intracellular $A \beta$ that is eventually released as an aggregate in the extracellular space.

To note, PS2 [23, 41], as well as APP and intermediate fragments of its metabolism [42, 43], were previously found in endo-lysosomal compartments and extracellular vesicles (EVs). We examined whether the extracellular hexamericlike A $\beta$ assemblies were present in EVs. A specific ultracentrifugation procedure was performed to separate EVs from soluble proteins in the media of PS1-KD, PS2-KD, and respective control cells (PS1-S, PS2-S). The accuracy of the EVs separation was validated by the Europium-immunoassay with, in the EVs, significantly increased levels of inclusion markers CD9, CD63, and CD81 and lower content of the exclusion marker GM130 (Fig. 4a, left panel). The specific enrichment of inclusion markers due to a higher protein content in EVs was ruled out since whole-protein assay showed larger protein amounts in soluble than EVs fractions (Fig. 4a, right panel). Importantly, extracellular monomeric $\mathrm{A} \beta$ was found exclusively in the soluble proteins fraction while hexameric $A \beta$ was confined exclusively in vesicles (Fig. 4c), in agreement with the recent observations on "A $\beta$-like" oligomeric species [44]. To note, EVs size distribution was similar between all conditions but the number of EVs was higher in PS1-KD and PS2-KD as compared to respective controls (Fig. $4 \mathrm{~b}$ ), indicating that the decrease in hexameric-like A $\beta$ assemblies observed in PS2-KD is not due to a decrease in EVs formation.

To assess whether the observed phenotype was truly dependent on PS2, we have re-expressed human wild-type PS2 in SH-SY5Y PS2-KD cells by lentiviral infection followed by selection. This resulted in efficient expression of PS2, as can be observed in Fig. 4d with a strong signal for PS2-CTF in PS2 rescued cells (PS2-R). We have repeated the Western blotting analysis on lysates and media samples (processed by ultracentrifugation to differentiate soluble proteins and EVs) from these cells, in parallel to PS2-S and 
a

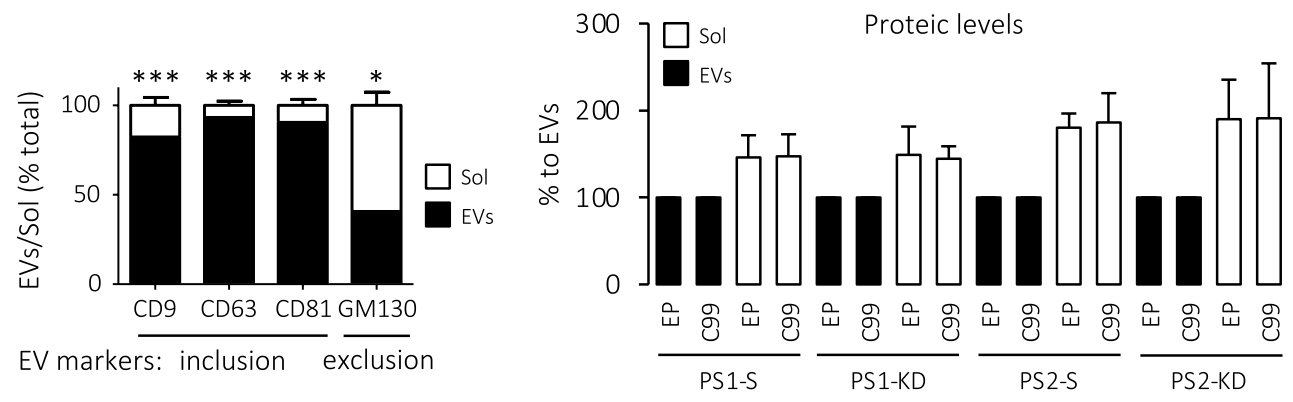

b

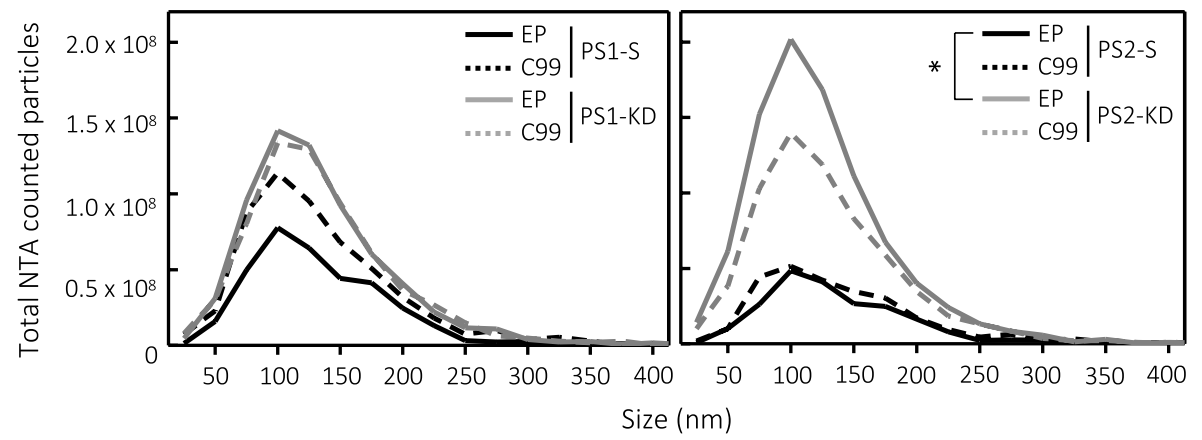

C

\begin{tabular}{|c|c|c|c|c|c|c|}
\hline \multicolumn{2}{|c|}{$\begin{array}{l}\text { Soluble } \\
\text { proteins }\end{array}$} & \multicolumn{2}{|c|}{$\begin{array}{l}\text { Extracellular } \\
\text { vesicles }\end{array}$} & \multirow{2}{*}{$\begin{array}{c}@ A \beta \\
(W 0-2)\end{array}$} & $\begin{array}{l}\text { Soluble } \\
\text { proteins }\end{array}$ & $\begin{array}{c}\text { Extracellular } \\
\text { vesicles }\end{array}$ \\
\hline PS1-S & PS1-KD & PS1-S & PS1-KD & & PS2-S PS2-KD & PS2-S PS2-KD \\
\hline
\end{tabular}
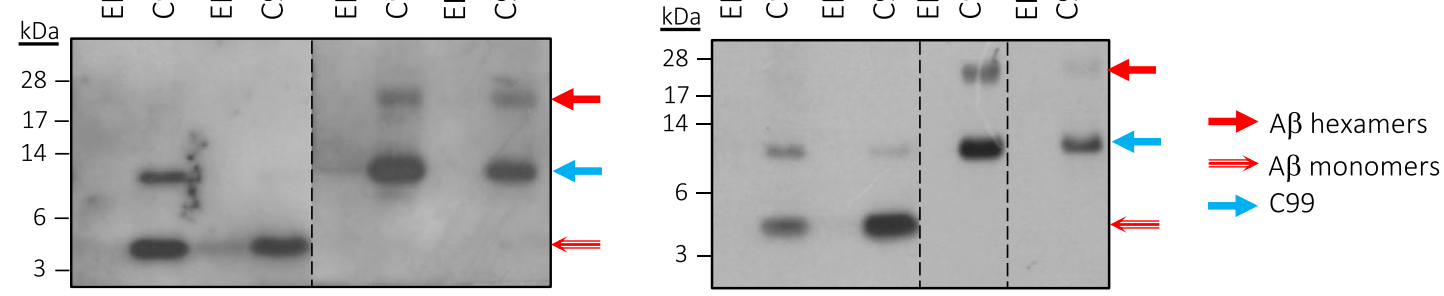

d

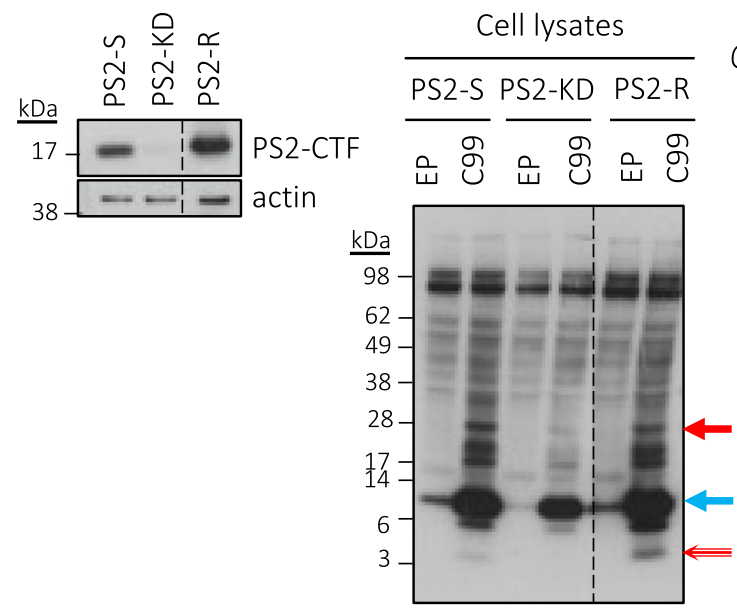

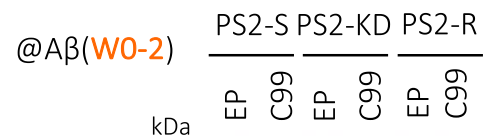
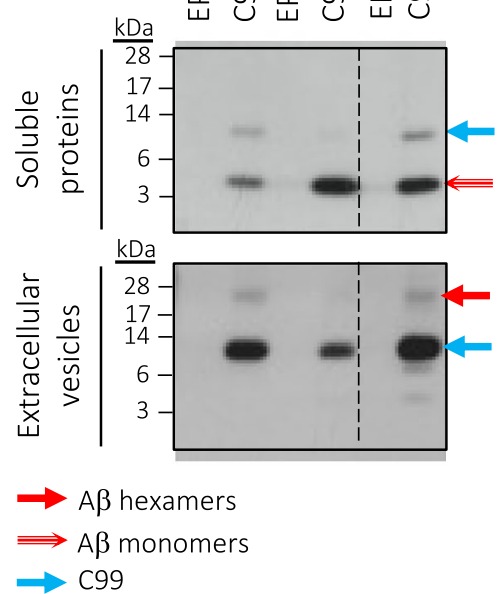
४Fig. 4 PS2-dependent release of hexameric A $\beta$ assemblies in extracellular vesicles (EVs). Complete media of PS1-S, PS1-KD, PS2-S, and PS2-KD cells underwent an ultracentrifugation process to separate putative enrichment of EVs, in pellet, from soluble proteins. a The efficiency of EVs isolation was confirmed by plate-based Europium-immunoassay (left panel) showing an enrichment of EVs inclusion markers CD9, CD63, and CD81, while EVs exclusion marker GM130 was lower in EVs as compared to soluble fractions. $N=6$. Mann-Whitney test: $* p<0.05, * * * p<0.001$ (CD9 $(n=22)$, CD63 $(n=22)$, and CD81 $(n=18): p<0.0001$; GM130 $(n=19)$ : $p=0.0362$ ). Quantification of protein levels by BCA (right panel) showed larger protein amounts in soluble than EVs fractions, ruling out the specific enrichment of inclusion markers due to higher content in proteins. b EVs ultracentrifugation pellets were counted for number of particles of $70-400 \mathrm{~nm}$ by nanoparticle tracking analysis (NTA). $n=9$ in $N=3$ independent experiments. Two-way ANOVA with Bonferroni's multiple comparison: ${ }^{*} p<0.05$ (PS2-KD EP vs PS2-S EP: $p<0.05$ ). $\mathbf{c}$ Both EVs and soluble extracts were monitored by Western blotting with the W0-2 antibody. Dashed lines indicate that proteins were run on the same gel, but lanes are not contiguous. d Human PS2 was re-expressed in PS2-KD cells to assess the restoration of observed phenotypes. The efficiency of re-expression was monitored using the PS2-CTF antibody in PS2 rescued (R) cells with comparison to PS2-S and PS2-KD cells (left panel). Cell lysates (middle panel) as well as extracellular soluble proteins (upper right panel) and EVs (lower right panel) were monitored by Western blotting with the anti-A $\beta$ (W0-2) antibody. $E P$ empty plasmid, $E V(s)$ extracellular vesicle(s), Sol soluble proteins fraction

PS2-KD cells. We found that, upon PS2 re-expression (PS2$\mathrm{R})$, the intracellular pool of $\mathrm{A} \beta$ monomers and the extracellular release of $\mathrm{A} \beta$ hexamers were both restored (Fig. 4d).

Together, our results indicate that PS2 plays a critical role in the release of hexameric-like $A \beta$ assemblies, liberated in the extracellular milieu through EVs. Importantly, proteins confined in EVs were previously suggested to play a pivotal role in amyloid plaques formation and $\mathrm{AD}$ [45], suggesting that the $A \beta$ hexamers identified here might be able to trigger specific aspects of the amyloid pathology. We thus next sought to investigate if similar hexameric-like $A \beta$ assemblies were present in a pathological context.

\section{Hexameric-Like $A \beta$ Assemblies in the Context of Amyloid Pathology}

We investigated the presence of similar $A \beta$ assemblies in mice expressing familial AD (FAD) mutations. We readily detected $\sim 28 \mathrm{kDa} \mathrm{A} \beta$ assemblies (Fig. 5a) in brain extracts of 5xFAD mice [29], likely corresponding to those we have identified as hexameric $A \beta$ in a cellular model. Interestingly, the intensity of hexameric-like $A \beta$ detection in $5 x F A D$ mice brains increased with age. To note, the detection of these assemblies preceded that of high molecular weight $\mathrm{A} \beta$ assemblies ( $>198 \mathrm{kDa}$ ) likely corresponding to fibrils, which are recognized as the major indicator of the development of amyloid deposits in the 5xFAD model [29, 46]. Quantitative analysis of $\mathrm{A} \beta$ hexamers $(\sim 28 \mathrm{kDa})$ and fibrils ( $>198 \mathrm{kDa}$ ) relative to the human APP expressed in mice brains confirmed the appearance of the $\sim 28 \mathrm{kDa} \mathrm{A} \beta$ assemblies as an early event (Fig. 5b). These assemblies accumulated first in the hippocampus of the mice, as early as 2-month-old, while their detection in cortical regions peaked at 3 to 6 months of age. This is in line with the staging of amyloid pathology observed in human $\mathrm{AD}$ and suggests that hexameric-like $A \beta$ assemblies might serve as an early indicator of amyloid pathology development and as an important contributor to its progression.

In addition, cerebrospinal fluid (CSF) samples from cognitively affected patients (diagnosed with non-AD dementia, pre-clinical $\mathrm{AD}$ or symptomatic $\mathrm{AD}$ ) were monitored with the same Western blotting approach (Fig. 5c, left panel). Only AD-related patients revealed the presence of $\sim 28 \mathrm{kDa}$ $\mathrm{A} \beta$ assemblies. Although the amounts of assemblies detected in the CSF remain quite low, their signal increases in symptomatic $\mathrm{AD}$ cases with respect to control or pre-clinical AD. This evidences the presence of hexameric-like $A \beta$ assemblies in the context of AD pathology for the first time. Full images of higher exposures can be found in Supplementary Fig.S5, while more detailed information on neurological examination and PET analyses conducted on the patients are displayed in Supplementary Table.S1. The same CSF samples were used for a quantitative analysis of monomeric $\mathrm{A} \beta$ isoforms by ECLIA immunoassay and revealed an overall reduction in the $A \beta_{42} / A \beta_{40}$ ratio in $A D$ patients (Fig. $5 \mathrm{c}$, right panel). This reduction correlated with the severity of AD symptoms shown by the patients (see raw values in Table.1), in agreement with previous reports [47]. On the contrary, relative quantification of hexameric-like $A \beta$ levels detected by Western blotting, using soluble APP (sAPP) as an intrasubject control, revealed an increase in the levels of hexameric-like $A \beta$ assemblies alongside the progression of AD (Table 1). This suggests a direct correlation between the reduced proportion of monomeric $\mathrm{A} \beta_{42}$ and its aggregation in the hexameric-like $\sim 28 \mathrm{kDa}$ assemblies, in line with the previous evidences of an inverse correlation between monomeric $\mathrm{A} \beta$ and higher $\mathrm{A} \beta$ assemblies in $\mathrm{AD}[48,49]$. In our study, statistical analysis revealed that $48.8 \%$ of the $\mathrm{A} \beta_{42} / \mathrm{A} \beta_{40}$ ratio variance can be explained by the increase in hexameric $A \beta$ formation.

\section{Cell-Derived Hexameric A $\beta$ Aggravates Amyloid Deposition in an AD Mouse Model and Decreases Cell Viability in Primary Neurons Expressing Human APP}

To further assess the potential of cell-derived hexameric $A \beta$ assemblies to trigger amyloid pathology, we performed hippocampal stereotaxic injections in two mouse models: (i) WT mice (C57BL/6) to assess the potential of $\mathrm{A} \beta$ hexamers to form amyloid deposits in a previously amyloid-free context, and (ii) mice developing amyloid pathology (5xFAD) 
a

2-month-old

3-month-old

6-month-old

9-month-old

12-month-old

@A (W0-2)

$@ A \beta(W 0-2)$

$@ A \beta(W 0-2)$

@A $($ WO-2)

$@ \mathrm{~A} \beta(\mathrm{W} 0-2)$

WT 5xFAD

WT $\underline{5 \times F A D}$

WT $\underline{5 \times F A D}$

WT 5XFAD

WT $\underline{5 \times F A D}$

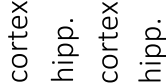

离

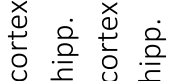

希离

苨
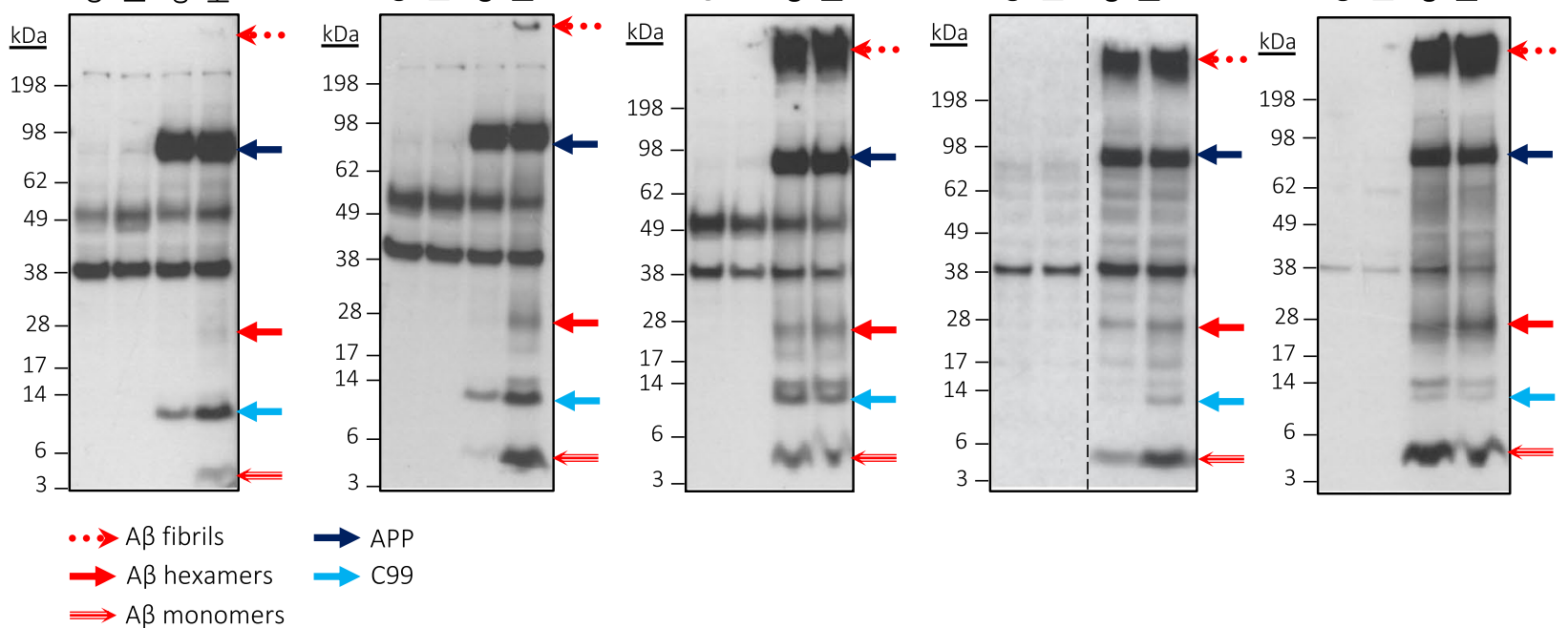

b
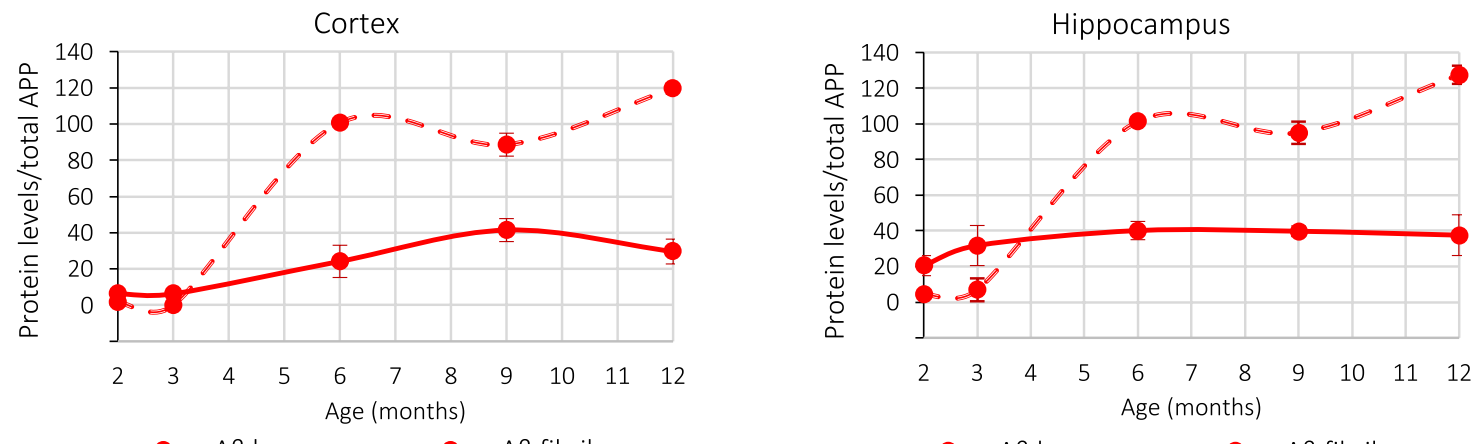

$-A \beta$ hexamers $-0-A \beta$ fibrils

$\longrightarrow A \beta$ hexamers $\because \bullet A B$ fibrils

C

$@ A \beta(W 0-2)$

$\frac{\text { Non-AD }}{\infty} \frac{\text { Precl.-AD }}{m} \frac{\text { Sympto. AD }}{\sim}$

$\underline{\mathrm{kDa}}$ $-$

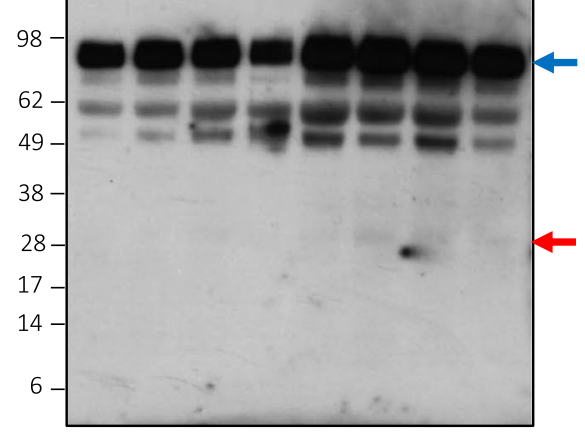

28

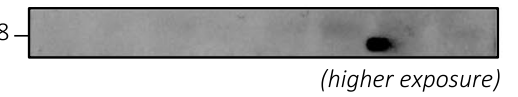

@APP-C-ter

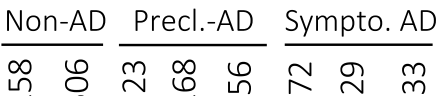
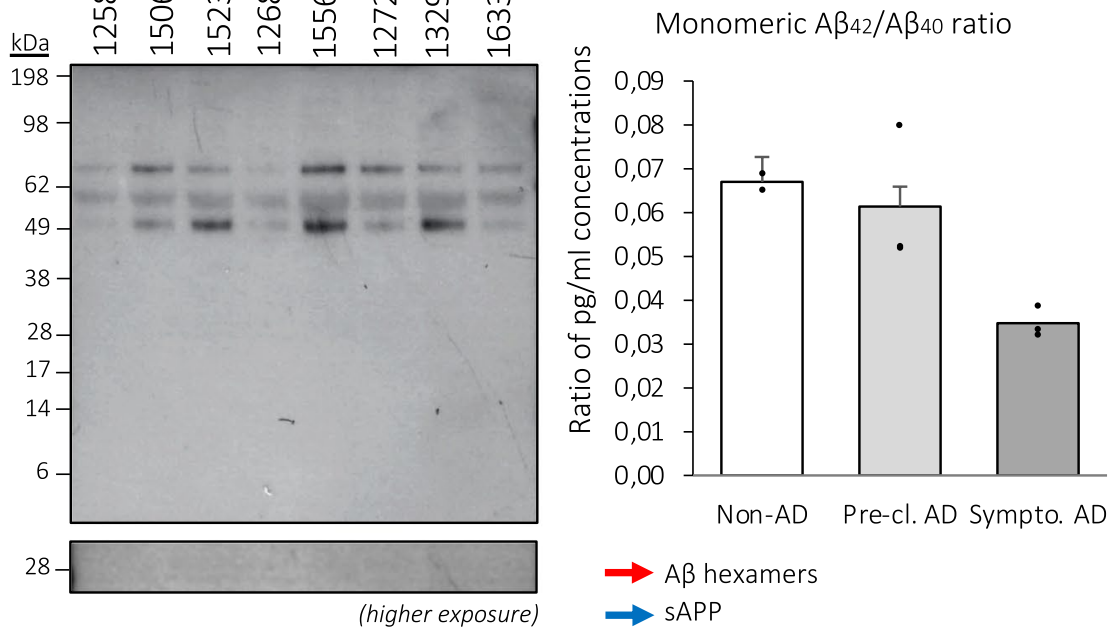
4Fig. 5 Identification of hexameric-like $A \beta$ assemblies in the context of $\mathrm{AD}$. a Detection of $\mathrm{A} \beta$ assemblies in brain samples from an amyloid mouse model (5xFAD). Cortices and hippocampi of euthanized mice were lysed and analyzed by Western blotting with the anti-A $\beta$ (W0-2) antibody. A $\beta$ fibrils appear stuck in the wells and hexameric-like $\mathrm{A} \beta$ assemblies are detected at $28 \mathrm{kDa}$. To note, $\mathrm{C} 99$ fragments $(\sim 10 \mathrm{kDa})$ and $\mathrm{A} \beta$ monomers $(\sim 4.5 \mathrm{kDa})$ are also detected in all 5xFAD samples and reflect an efficient metabolism of the human APP protein expressed in these mice. Dashed lines indicate that proteins were run on the same gel, but lanes are not contiguous. Hipp. hippocampus. $\mathbf{b}$ The signal intensities of $A \beta$ hexamers and $A \beta$ fibrils were quantified relatively to the APP signal. Samples used for quantitative analysis derived from the same experiment, with Western blots processed in parallel. The displayed graphs represent the profile of $\mathrm{A} \beta$ assemblies as related to both the analyzed brain area (cortex, hippocampus) and the age (2, 3, 6, 9, 12 months of age) ( $\min N=3$ each). c Identification of $\sim 28 \mathrm{kDa}$, hexameric-like, $\mathrm{A} \beta$ assemblies in the cerebrospinal fluid (CSF) of AD patients. Western blotting analysis was performed using the anti-A $\beta$ (W0-2) and anti-APP-C-ter antibodies. Higher exposures were performed for a better appreciation of the bands of interest; full images can be found in Supplementary Fig.S5. Dosage of monomeric $A \beta_{42} / A \beta_{40}$ by ECLIA immunoassay confirmed the correct classification of individuals, with a reduction in ratio along with AD progression. $s A P P$ soluble APP, Pre-cl. Preclinical, Sympto. symptomatic

to mimic a situation where the hexamers are incubated with pre-existing $A \beta$, to serve as seeds driving the assembly and deposition of $\mathrm{A} \beta$ produced in the brain. Experimental workflow is represented in Fig. 6a. The isolated assemblies were obtained by W0-2-immunoprecipitation and GELFrEETM separation of C42-expressing $\mathrm{CHO}$ cells media as described above (Fig. 1) [15]. The corresponding GELFrEE ${ }^{\mathrm{TM}}$ fraction of cells expressing the empty plasmid (EP) was used as a control. The fraction of cell-derived hexameric $\mathrm{A} \beta$ was diluted from 150 to $15 \mu \mathrm{M}$ prior to intracerebral injection. The control fraction was diluted in a similar manner. Specific detection of diluted cell-derived hexameric $\mathrm{A} \beta$ was confirmed by dot blotting with the W0-2 antibody (Fig. 6a, left panel). 2-month-old WT or 5xFAD mice were injected in the hippocampus of the left and right hemisphere with $2 \mu 1$ of EP (control) and C42 (cell-derived hexameric A $\beta$ ) diluted fractions, respectively. To evaluate $\mathrm{A} \beta$ deposition, mice were sacrificed 30 days after stereotaxic injection and coronal sections of fixed brains were co-stained with the human-specific W0-2 antibody for $\mathrm{A} \beta$ and the Thioflavin $\mathrm{T}$ (ThT) dye for fibrillar aggregates. Quantitative analysis of A $\beta$ deposition was performed by counting double-positive dots (as indicated in Fig. 6a). The results showed that cellderived hexameric $\mathrm{A} \beta$ assemblies do not have the ability to form fibrillar deposits by themselves in a WT brain (Fig. 6b), but are capable of enhancing the deposition of $\mathrm{A} \beta$ already present in the $5 x$ FAD brain (Fig. 6c). In transgenic mice, the overall deposition of $A \beta$ in the hemisphere injected with cell-derived hexameric A $\beta$ showed a significant 1.47-fold increase when compared to the control-injected hemisphere (average $( \pm$ SEM) of $32.39( \pm 3.49)$ and $47.50( \pm 4.74)$ deposits per field in control- and hexamer-injected hemispheres, respectively). Deposits were further investigated in the two regions mainly affected by amyloid pathology in AD: the hippocampus and the cortical areas (Fig. 6c). As expected, the highest increase in $A \beta$ deposition was observed in the hippocampal region, where stereotaxic injections were performed (2.90-fold increase relative to control). However, levels of $\mathrm{A} \beta$ deposits were also significantly increased by a 1.74-fold in the cortex. This suggests that the injected cellderived hexameric $A \beta$ assemblies are able to propagate from the hippocampal formation to associated cortical regions to promote amyloidosis.

We finally assessed whether isolated cell-derived hexameric $\mathrm{A} \beta$ was capable of exerting neurotoxic effects. To that end, we cultured primary neurons from wild-type (WT) and transgenic (5xFAD) embryos and treated them after 7 days of differentiation in vitro (DIV) with isolated hexameric $A \beta$ assemblies. As for in vivo seeding assays, $A \beta$ hexamers were obtained by W0-2-immunoprecipitation and GELFrEE ${ }^{\mathrm{TM}}$ separation of $\mathrm{C} 42$-expressing $\mathrm{CHO}$ cells media and the corresponding fraction of EP-expressing $\mathrm{CHO}$ cells media was used as a control. Two final concentrations were tested; $1 \mu \mathrm{M}$ and $5 \mu \mathrm{M} .24 \mathrm{~h}$ after treatment, cell viability was assessed using a ReadyProbes $®$ assay and a percentage of dead cells out of the total cells was quantified (Fig. 7a). Results showed no significant cytotoxic effect at tested concentrations on primary neurons cultured from WT mice (Fig. 7b), even though both are above the reported neurotoxic concentrations from preparations of synthetic oligomeric A $\beta[6,50]$. This suggests that the identified assemblies are not cytotoxic per se, at least in these experimental conditions. However, primary neurons cultured from 5xFAD mice, which can serve as an amyloid model in vitro [51-53], displayed increased cell death when exposed to $5 \mu \mathrm{M}$ of cell-derived hexameric $\mathrm{A} \beta$ (Fig. 7c). Importantly, this indicates that hexameric $A \beta$ assemblies may have the ability to cause toxic effects only when there is pre-existing $A \beta$ in the neuronal environment. This therefore implies that such cytotoxic properties require the intermediate seeding of other available $A \beta$ forms.

\section{Discussion}

The identification of fibrillar $\mathrm{A} \beta$ as the main component of amyloid plaques present in $\mathrm{AD}$ has led to the extensive investigation of the $\mathrm{A} \beta$ self-assembly process and, as a result, to the identification of many intermediate oligomeric assemblies of A $\beta$. Today, it is widely admitted that such non-fibrillar, soluble assemblies can exert a widespread neurotoxic effect and should be the main target of therapeutic prevention or intervention. Among A $\beta$ oligomers, hexameric $\mathrm{A} \beta$ has repeatedly been identified as a key assembly in vitro $[3,8,11,54]$. Studies performed on synthetic preparations 
Table 1 Inverse correlation between monomeric and hexameric-like $\mathrm{A} \beta$ in human CSF samples

\begin{tabular}{llll}
\hline Inclusion $n^{\circ}$ & Classification & $\mathrm{A} \beta_{42} / \mathrm{A} \beta_{40}$ & $\begin{array}{l}\text { Hexameric } \\
\mathrm{A} \beta / \mathrm{sAPP}\end{array}$ \\
\hline 1258 & Non-AD & 0.069 & 0.079 \\
1506 & & 0.065 & 0.055 \\
1523 & Pre-clinical AD & 0.052 & 0.075 \\
1268 & & 0.080 & 0.084 \\
1556 & & 0.052 & 0.092 \\
1272 & Symptomatic AD & 0.033 & 0.140 \\
1329 & & 0.039 & 0.224 \\
1633 & & 0.032 & 0.143 \\
\hline
\end{tabular}

CSF samples from eight subjects were monitored in this study: patients $n^{\circ} 1258$ and 1506 did not exert any AD-related features. Patients $n^{\circ} 1523,1268$, and 1556 were diagnosed with pre-clinical $\mathrm{AD}$ and patients $n^{\circ} 1272,1329$, and 1633 with symptomatic AD. Ratios of monomeric $A \beta_{42}$ over monomeric $A \beta_{40}$, and of hexamericlike A $\beta$ over soluble APP (sAPP) were obtained from ECLIA and Western blot quantifications, respectively (see Fig. 5). Pearson's $R$ correlation test: $R=-0.70(R$-squared $=0,49), p=0.05$

of $A \beta$ have shed light on the crucial role of $A \beta$ hexamers in the nucleating step of $A \beta$ self-assembly $[11-13,55]$. However, such studies have not, to the best of our knowledge, characterized the production of hexameric $\mathrm{A} \beta$ in a cellular environment, nor assessed its toxic potential and relevance to $\mathrm{AD}$ pathogenesis. Our work shows that specific $\sim 28 \mathrm{kDa} A \beta$ assemblies are produced in a wide range of biological models. Using $\mathrm{CHO}$ cells, we were able to confirm the nature of these assemblies as hexameric $\mathrm{A} \beta_{42}$ [15]. The question of whether these assemblies are exclusively formed by six $\mathrm{A} \beta_{42}$ monomers associated together would require extensive analytical biochemistry investigation, which are of real interest, but beyond the scope of this study. Nevertheless, a major finding here is that the $A \beta$ assemblies we investigated across different cell lines (i) have an apparent molecular weight around $28 \mathrm{kDa}$; (ii) are recognized by W0-2, 6E10, and anti-A $\beta_{42}$ antibodies but not by anti-APP-C-ter or anti-A $\beta_{40}$ antibodies; and (iii) are affected by the knockdown of PS2, a catalytic subunit of the $\gamma$-secretase complex. Our recently reported aggregation assays revealed a seeding potential of the isolated assemblies when incubated with recombinant monomeric $A \beta$ in vitro [15]. Together, this clearly indicates that the identified $A \beta$ assemblies contain $A \beta_{42}$ and have not only the theoretical size, but also the expected properties of $\mathrm{A} \beta$ hexamers.

With this important observation in mind, we sought to better understand the cellular context in which hexameric $\mathrm{A} \beta$ is produced. In particular, we assessed the respective involvement of both presenilins in its production. Indeed, the distinct subcellular localizations [23] and differential substrate specificities [21] of PS1 and PS2 control the production of different $A \beta$ pools. Production of $A \beta$ can differ considerably between cellular compartments [23]. Pathological $A \beta$ formation is related to dysfunction of the endocytic pathway, and PS1 and PS2 are differentially distributed between the secretory compartments and the late endosomes/lysosomes, to which PS2 is shuttled [23]. Our results showed the absence of any significant change in the processing of $\mathrm{C} 99$ or in the release of $\mathrm{A} \beta$ when cells have a nearly 50\% reduction of PS1 protein levels. This was rather unexpected regarding the previous reports on the preponderant importance of PS1 for $\gamma$-secretase substrates cleavage and overall $A \beta$ production [17-21]. One can imagine, as already mentioned above, that the reduction of PS1 protein levels is not significant enough to observe any effect. PS1 knockdown might induce compensatory mechanisms and still ensure its primary function even when its protein levels are reduced by half. In the PS2 knockdown cells, the reduction of PS2 protein levels by just over $60 \%$ was sufficient to cause clear changes in $\mathrm{A} \beta$ production. While the initial cleavage of the $\mathrm{C} 99$ construct remained unaffected, the production of monomeric $A \beta$ was strongly diminished inside the cell. This is linked with the previous reports suggesting that the intracellular pool of $A \beta$ is mostly generated through the activity of PS2 [23]. In an opposite manner, the production of monomeric $A \beta$ was strongly increased in the extracellular medium. In particular, the $\mathrm{A} \beta_{40}$ isoform was increased in the medium of PS2-KD cells. The levels of the $\sim 28 \mathrm{kDa}$ hexameric $\mathrm{A} \beta$ assemblies were unchanged in the cell lysates but strongly diminished in the extracellular environment.

Importantly, we observed for the first time that specific $\mathrm{A} \beta$ assemblies were enriched in extracellular vesicles, while monomeric $\mathrm{A} \beta$ was present solely in the soluble fraction. Although the amount of EVs tended to increase upon knockdown of PS1/PS2, it did not seem to impact A $\beta$ fate. As PS1 and PS2 have been, respectively, shown to produce the extra- and intracellular pools of $A \beta$ [23], the direct release of soluble $A \beta$ outside the cellular environment is likely to rely mostly on the action of PS1, while the intracellular pool is likely to mainly result from PS2-dependent $\gamma$-secretase activity in endocytic compartments. Previous reports suggest that the PS2-dependent cleavage mainly occurs in a specific subset of endosomes and leads to the presence of $A \beta$ in multivesicular bodies (MVBs) which, after fusion with the cell membrane, can release their $\mathrm{A} \beta$-containing intraluminal vesicles as EVs in the extracellular milieu [45].

As PS2-dependent cleavage was reported to predominantly produce intracellular aggregation-prone $\mathrm{A} \beta_{42}$ [23], it is likely that the monomeric $A \beta$ formed along the endocytic-EVs pathway corresponds to $A \beta_{42}$ and extensively aggregates inside vesicles, evidently as hexameric $A \beta_{42}$. On the other hand, the soluble monomeric $A \beta$ that is produced through the PS1-dependent secretory pathway likely corresponds to $A \beta_{40}$, which might not be able to aggregate. This is supported by observations reported in our recent 
biochemical in vitro study [15], indicating that soluble monomeric $\mathrm{A} \beta$ present in the medium of $\mathrm{C} 99$-expressing $\mathrm{CHO}$ cells corresponds to non-aggregating $\mathrm{A} \beta_{40}$. To note, the increase in the extracellular levels of soluble monomeric $\mathrm{A} \beta_{40}$ observed in PS2-KD cells likely reveals a PS1dependent compensatory mechanism taking place upon PS2 knockdown.

Together, our results in both knockdown cell lines drive towards the hypothesis that extracellular hexameric $\mathrm{A} \beta$ found in EVs might stem from MVBs and thus from the intracellular pool of $\mathrm{A} \beta$, a process controlled by PS2 activity. The identification of such a specific role for PS2 in the release of hexameric $A \beta$ is of particular importance. It is quite promising in the hope of re-evaluating $A \beta$ modulators and developing therapeutic agents specifically targeting PS2-dependent $\gamma$-secretase complexes. To note, PS1 and PS2 were reported to have different sensitivities to $\gamma$-secretase inhibitors [21]. Importantly, the intracellular pool of A $\beta$, generated by PS2, has been repeatedly associated with the progression of AD [56-59]. FAD mutations in PSEN2 have been shown to dramatically increase the proportion of longer $A \beta$ fragments intracellularly, accelerating its assembly. Further, a subset of familial mutations on PSEN1 have been reported to shift the localization of the PS1 protein to fit that of PS2 [23]. Thus, it is likely that the PS2-dependent production of aggregation-prone $A \beta$ inside intracellular compartments and its resulting accumulation and excretion are enhanced in the context of AD.

In line with this, we also report for the first time the presence of hexameric-like $A \beta$ assemblies in brain extracts from a well-characterized amyloid mouse model (5xFAD) as well as in the CSF of AD patients. This supports that hexameric $A \beta$ may act as an important actor in the amyloid pathology. In the 5xFAD model, the presence of hexameric-like $A \beta$ assemblies followed a regional pattern of progression that corresponds to the neuropathological, clinical staging of human AD pathogenesis [60]. Indeed, the $\sim 28 \mathrm{kDa}$ assemblies were detected first in the hippocampus, as early as 2-month-old, and further spread to the cortex starting from 3- to 6-month-old. On the contrary, amyloid plaques formation in the 5xFAD mice have previously been reported to appear first in deep layers of the cortex and in the subiculum, and to later spread to the hippocampus as mice aged [29]. As the spreading properties of soluble $A \beta$ oligomers are likely to depend on the initial site where they are formed, investigating the aggravation of amyloid pathology upon injection of cellderived hexameric $A \beta$ in the cortical areas might bring important evidence to support this hypothesis. Meanwhile, the pattern of detection of hexameric-like $\mathrm{A} \beta$ assemblies reported here suggest that they could represent early biomarkers of amyloid pathology. The detection of similar $\sim 28 \mathrm{kDa}$ assemblies in CSF extracted from human patients diagnosed with pre-clinical $\mathrm{AD}$ and symptomatic AD supports this hypothesis.

The isolation of hexameric $\mathrm{A} \beta$ from our $\mathrm{CHO}$ cell model has also allowed for the characterization of its pathological properties. More precisely, we assessed the contribution of isolated cell-derived hexameric $\mathrm{A} \beta$ to both (i) amyloid deposition upon stereotaxic injection in mouse brains and (ii) cytotoxicity upon direct exposure to primary neurons. We assessed this in both (i) wild-type (WT) mice, to evaluate the intrinsic pathological properties of hexameric $\mathrm{A} \beta$, and (ii) transgenic 5xFAD mice, to evaluate the ability of hexameric $\mathrm{A} \beta$ to aggravate the development of amyloid pathology.

Using WT mice, we found that hexameric $A \beta$ assemblies were not able to induce $A \beta$ deposition nor elicit any cytotoxic effect per se. To note, $A \beta$ deposition in vivo was assessed in a timeframe of 30 days and one cannot exclude that pathogenic events might take place upon longer incubation time. In addition, the absence of $A \beta$ deposits formation (stereotaxic injections) or cytotoxicity (cultured neurons) induced by cell-derived hexameric $A \beta$ does not exclude its ability to alter brain function apart from amyloid deposition or cytotoxicity. Indeed, cellular dysfunctions or alterations of neuronal connectivity might occur in our WT models without leading to detectable amyloidosis or significant neuronal death. The absence of $A \beta$ deposits after injection of cell-derived hexameric $A \beta$ in the brain of WT mice also does not exclude the possibility that the stable seeds injected might not directly cause amyloidosis in the injected animals, but persist in the brain and retain pathogenic properties, as was previously shown with second-transmission studies [7]. Interestingly, observations taken from aggregation assays revealed that hexameric $\mathrm{A} \beta$ assemblies are very stable when incubated alone in vitro, and unable to further aggregate into higher molecular weight complexes [15]. The lack of direct neurotoxic effects of the studied assemblies is thus in agreement with the fact that (i) the process of $A \beta$ self-assembly is thought to be vital in mediating cytotoxicity $[33,61]$ and that (ii) the pathological properties of $A \beta$ oligomers could rely not only on their synaptotoxic effects but also on their seeding properties, propagating amyloid pathology throughout the brain parenchyma.

Considering the suggested role of hexameric $\mathrm{A} \beta$ as a nucleus for $A \beta$ self-assembly, we wondered whether the harmful potential of $A \beta$ hexamers could be unraveled when pre-existing $A \beta$ species are present. Indeed, a major observation in this study is the ability of cell-derived hexameric $\mathrm{A} \beta$ to act as a seeding nucleus and cause both aggravation of cerebral $\mathrm{A} \beta$ deposition and cytotoxicity in primary neurons of transgenic 5xFAD mice. These mice express five familial $\mathrm{AD}$ mutations that together trigger $\mathrm{A} \beta_{42}$ overproduction and result in a rapid and severe development of amyloid pathology $[29,46]$. 5xFAD mice therefore represented an accurate model to assess the nucleating properties of cell-derived 
a

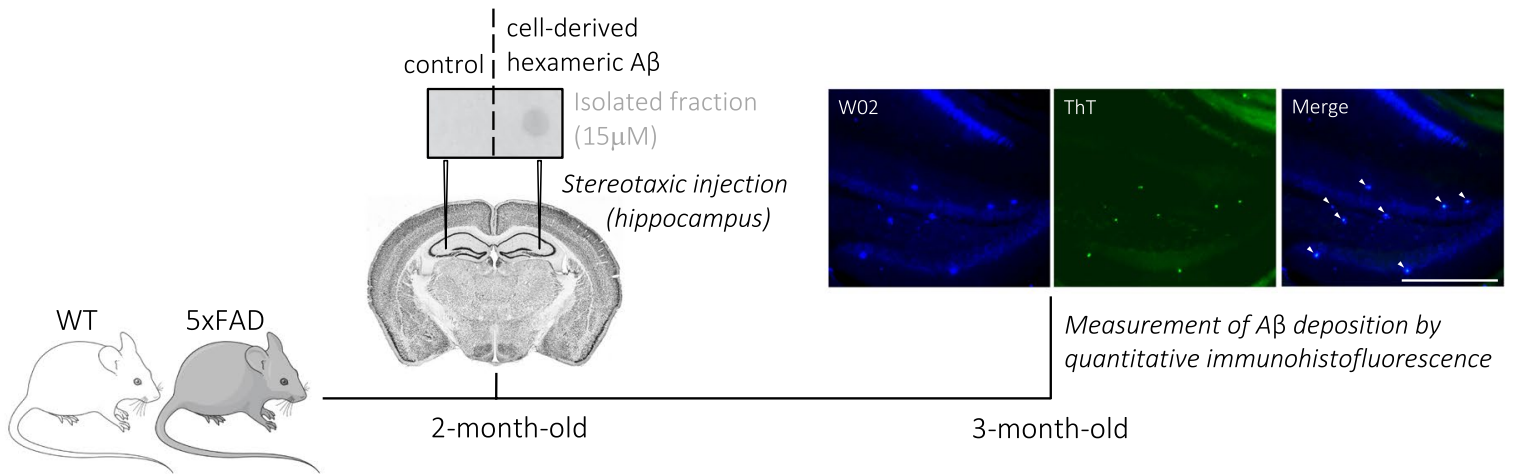

\section{b $\square$ control $\square$ cell-derived hexameric $A \beta$}

$A B$ deposition in WT mice

(full hemisphere)
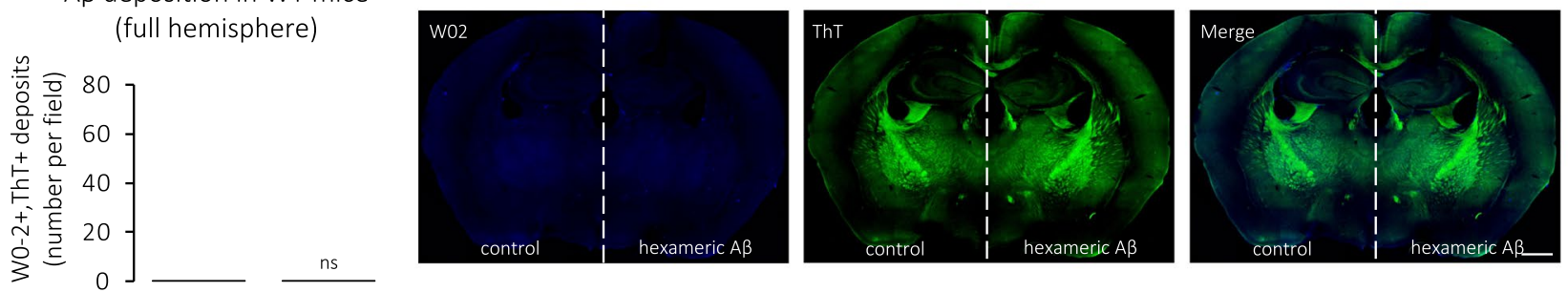

C $\square$ control $\square$ cell-derived hexameric $A B$

$A \beta$ deposition in $5 \times F A D$ mice (full hemisphere)
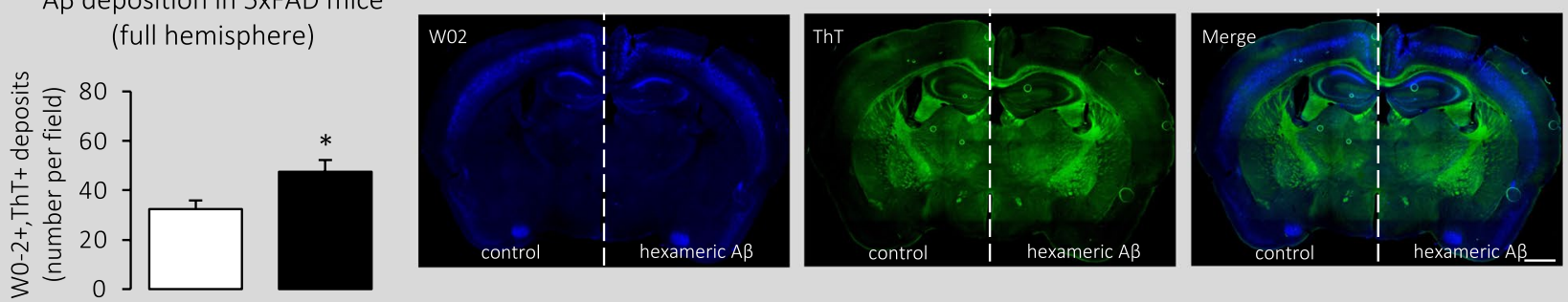

$A \beta$ deposition in $5 \times F A D$ mice
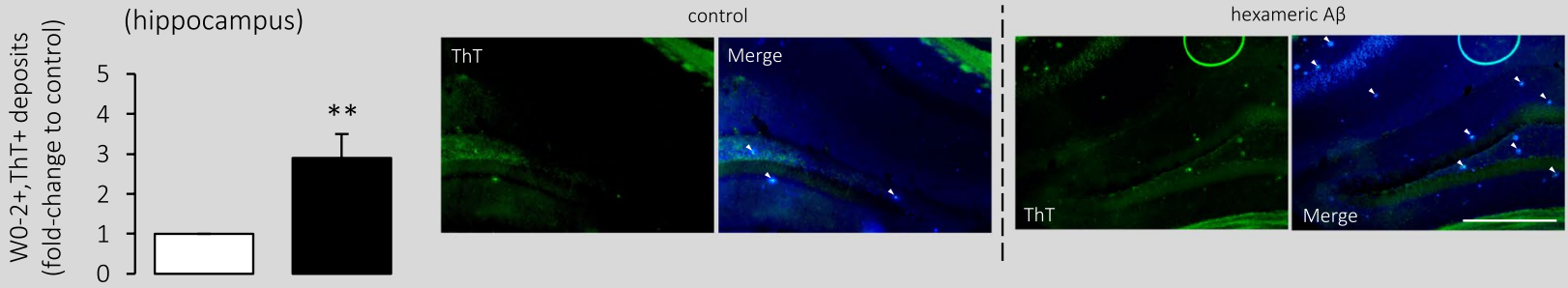

$A \beta$ deposition in $5 \times F A D$ mice
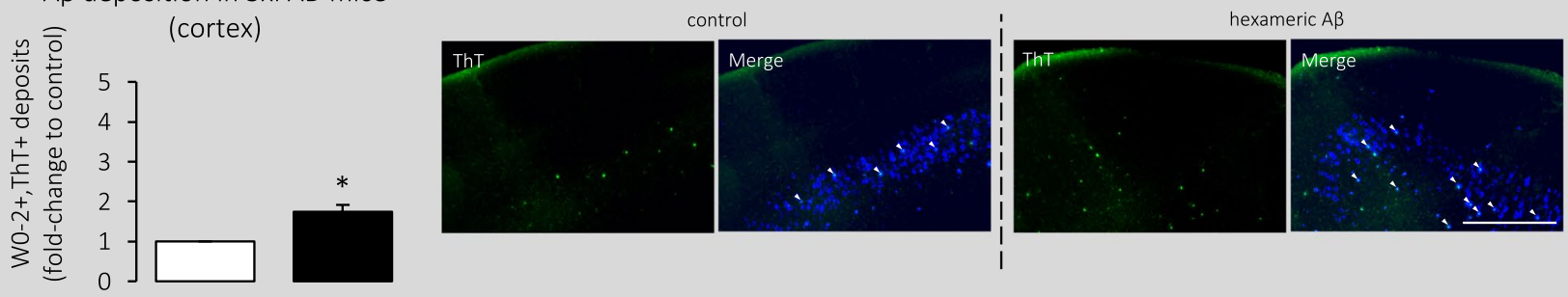

hexameric $A \beta$ assemblies in vivo in a reasonable timeframe. An earlier onset of $A \beta$ aggregation in this model was previously reported upon single intracerebral injection of brain homogenates containing oligomeric $\mathrm{A} \beta$, following a prionlike seeding mechanism [62]. A $\beta$ oligomers have been further suggested to be early triggers of the seeding process, as 
4Fig. 6 Intracerebral injection of cell-derived hexameric A $\beta$ in WT and 5xFAD mice. a Experimental workflow. 2-month-old mice were deeply anesthetized, placed in a stereotaxic apparatus and bilaterally injected with $2 \mu \mathrm{l}$ of either $15 \mu \mathrm{M}$ GELFrEE $^{\mathrm{TM}_{-} \text {-isolated } \mathrm{A} \beta}$ hexamers $(\mathrm{C} 42)$ or control $(\mathrm{EP})$ in the hippocampus $(\mathrm{A} / \mathrm{P}-1.94$; $\mathrm{L}+-2.17$; $\mathrm{D} / \mathrm{V}-1.96$; $\mathrm{mm}$ relative to bregma). Both fractions were analyzed by dot blotting prior to injection. 30 days later, mice were transcardially perfused, brains were fixed, and coronally sectioned $(50 \mu \mathrm{m})$. Immunostaining was performed on free-floating sections using the anti-human $\mathrm{A} \beta$ (W0-2) antibody as a marker for $\mathrm{A} \beta$ and the Thioflavin T (ThT) dye as a marker for fibrillar deposits. W0-2 and ThT staining were detected with FITC/Cy5 and GFP filters, respectively. Right panel displays an example of double-positive counting. Scale bar $=400 \mu \mathrm{m}$. b, c Quantification of fibrillar deposits in full hemispheres of WT (in b) and 5xFAD brains (in c. upper panel) injected with control vs hexameric A $\beta$. Scale bar $=1000 \mu \mathrm{m} . n=32$ slides from $N=8$ mice for both WT and 5xFAD. Mann-Whitney test: $n s$ non-significant, ${ }^{*} p<0.05$ (in WT: $p>0.99$ control vs hexameric A $\beta$; in 5xFAD: $p=0.04$ control vs hexameric $\mathrm{A} \beta$ ). For transgenic mice, deposits were also classified according to the two most affected brain regions, hippocampus and cortex, as a function of the control-injected hemisphere (in c middle and lower panel, scale bar $=400 \mu \mathrm{m}$ ). A 2.90 -fold and a 1.74-fold increase were observed in the hippocampus and cortex, respectively. One-sample Wilcoxon signed-rank test with hypothetical value set at $1: * p<0.05, * * p<0.01$ (in $5 \mathrm{xFAD}$ hippocampus: $p=0.008$ control vs hexameric $\mathrm{A} \beta$; in $5 \mathrm{xFAD}$ cortex: $p=0.02$ control vs hexameric $\mathrm{A} \beta$ )

their depletion by passive immunization delays $A \beta$ aggregation and leads to a transient reduction of seed-induced $A \beta$ deposition [63]. Our study has the advantage of focusing on a specific cell-derived $A \beta$ aggregate, that is heavily involved in the processes of nucleation and seeding as shown in recent in vitro studies $[11,15]$. We performed intracerebral injections at 2 months of age, when amyloid deposition begins in the 5xFAD mice [29]. The significant increase of $A \beta$ deposition observed in hexamer-injected hemispheres suggests that hexameric $\mathrm{A} \beta$ is indeed able to promote amyloidosis. As very recent in vitro studies from our group revealed the ability of the isolated $A \beta$ hexamers to drive the aggregation of synthetic monomers of $A \beta$ in vitro [15], it is likely that the enhancement in $A \beta$ deposition observed here in vivo relies on the same process of nucleation, with $A \beta$ hexamers serving as a template for aggregation. The greater increase of $A \beta$ deposition in the hippocampus when compared to the cortex of the injected mice supports this hypothesis, as hexameric $A \beta$ is likely to seed and promote $A \beta$ aggregation to a higher rate at the injection site. Still, the significant aggravation of $\mathrm{A} \beta$ deposition observed in the cortex also suggests that hexameric $A \beta$ is able to spread throughout the brain, as rapidly as in 30 days. Together, these observations suggest that hexameric $\mathrm{A} \beta$ is a key factor in the amyloidosis process, with seeding properties and ability to spread through connected brain regions, and might serve when naturally present as an early indicator of $\mathrm{A} \beta$ deposition. Cytotoxic assays on primary neurons derived from transgenic $5 \mathrm{xFAD}$ mice were also performed, since cultured neurons from $A D$ transgenic animal models express APP metabolites involved in amyloid pathology and can reflect AD phenotypes in vitro [51-53]. We observed a significant increase in the proportion of cell death when neurons were treated with $5 \mu \mathrm{M}$ of cell-derived hexameric $A \beta$. This suggests that these specific assemblies can indeed exert a toxic effect in a FAD context, where human $A \beta$ to seed is available.

\section{Conclusions}

Altogether, our findings have shed light on a particular cell-derived $A \beta$ assembly that corresponds to an $A \beta_{42}$ hexamer. An insight in cellular mechanisms at stake suggests a strong contribution of PS2 to the formation of this particular $A \beta$ oligomer, which is released in the extracellular milieu inside vesicles. This in line with the previous reports linking the restricted location of PS2 in acidic compartments of the endocytic pathway, from which extracellular vesicles can form, to the production of more aggregation-prone $A \beta$. Combining in vitro and in vivo approaches, we have revealed an absence of detrimental effects of cell-derived hexameric $A \beta$ by itself, but its capacity to aggravate amyloid deposition and induce cytotoxicity when there is $A \beta$ to seed at disposal.

Supplementary Information The online version contains supplementary material available at https://doi.org/10.1007/s12035-021-02567-8.

Acknowledgements We thank Esther Paître, Sarah Houben and Pierre Burguet for technical support. We are grateful to Jean-Noël Octave, Nathalie Pierrot, and Jean-Pierre Brion for providing scientific input as well as materials and animal models.

Author Contributions CV designed and performed experiments, analyzed and interpreted data, and wrote the manuscript. DMV performed experiments and analyzed data. NS and SC provided neuronal cultures and analyzed data. LD'A performed nanoparticle tracking and Europium-immunoassay analyses on isolated EVs, and helped with the analysis of related data. FP participated in experiment design and analysis. VVP and BH together provided the human CSF specimens. $\mathrm{BH}$ provided significant input in the interpretation of clinical data. LQ provided the GELFrEE ${ }^{\mathrm{TM}}$ technique and contributed to data collection. PKC designed and supervised the research project and contributed to interpretation of data. All authors read and approved the final manuscript.

Funding This work was supported by a grant of the Belgian F.N.R.S FRIA (Fonds National pour la Recherche Scientifique) and a grant of UCLouvain Fonds du Patrimoine to CV. Funding to PKC is acknowledged from SAO-FRA Alzheimer Research Foundation, Fondation Louvain and Queen Elisabeth Medical Research Foundation (FMRE to PKC and LQ). The work was supported by funds from FNRS Grant PDRT.0177.18 to PKC and LQ.

Data Availability All datasets generated and analyzed during this study are included in this published article and its supplementary information files. Materials are available upon request. 
a

Primary culture

of WT/5xFAD

neurons (E17)
Seeding in $12 \mathrm{w}$

(100.000 cells $\left./ \mathrm{cm}^{2}\right)$

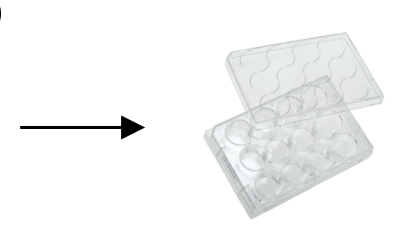

DIV7: treatment with control/cell-derived hexameric $A \beta$ ( 1 or $5 \mu \mathrm{M})$
DIV8: ReadyProbes ${ }^{\circledR}$ cell viability assay
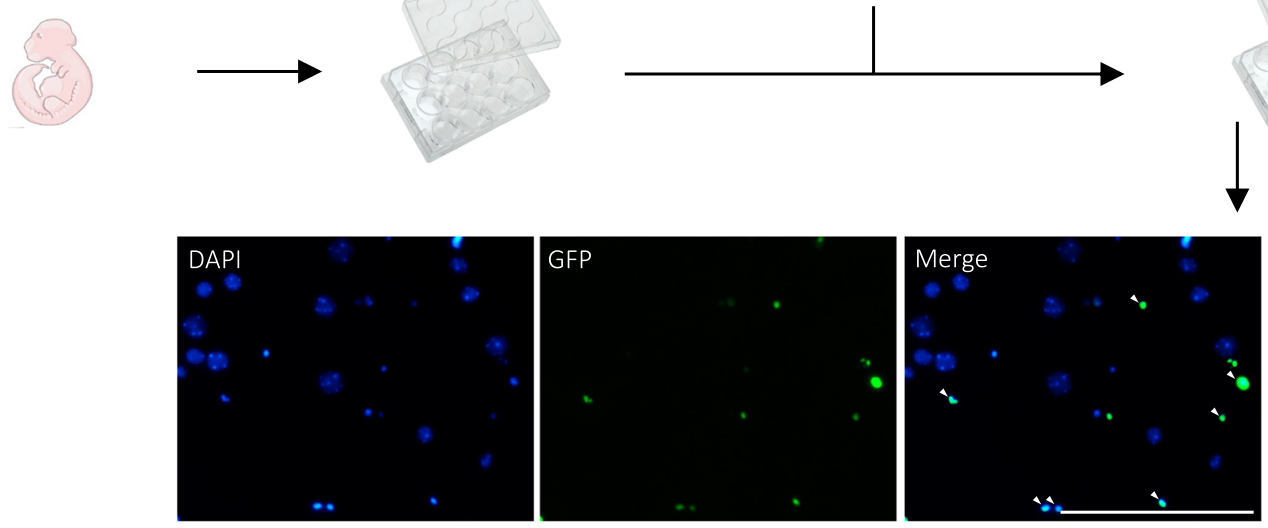

Counting of dead cells (DAPI+GFP+) out of total cells (DAPI+)

b

\section{Primary neurons from WT mice}

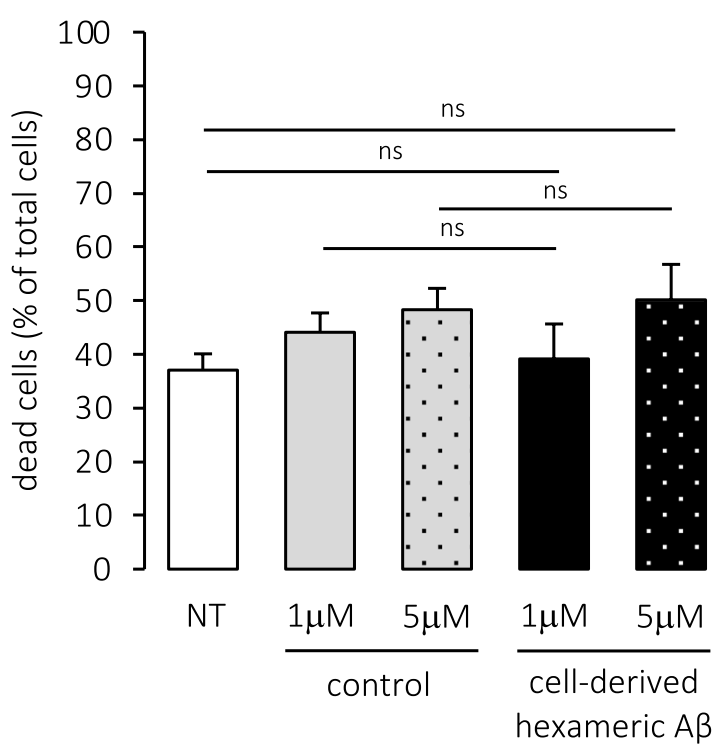

C Primary neurons from 5xFAD mice

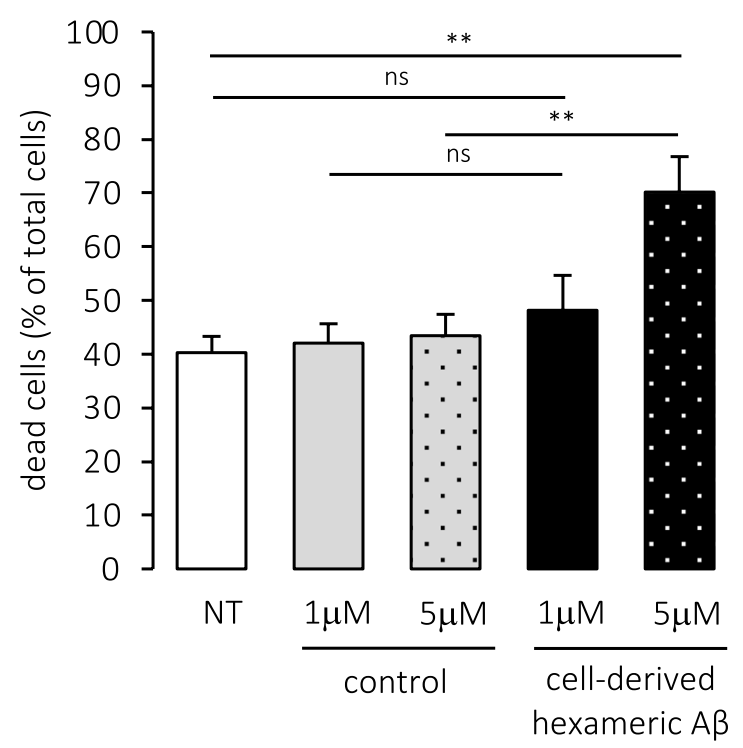

Fig. 7 Cell-derived hexameric $\mathrm{A} \beta$ assemblies are only cytotoxic in primary neurons that express amyloid proteins. a Experimental workflow. Primary neurons were isolated from wild-type (WT) or transgenic $(5 \mathrm{xFAD})$ mouse embryos at stage E17 and cultured for 8 days in vitro (DIV). At DIV7, cells were incubated for $24 \mathrm{~h}$ with $1 \mu \mathrm{M}$ or $5 \mu \mathrm{M}$ of cell-derived hexameric $\mathrm{A} \beta$ or control, isolated from the media of C42- and EP-expressing CHO cells, respectively. Cell viability was assessed using the ReadyProbes ${ }^{\circledR}$ assay and fluorescent staining was captured at an EVOS ${ }^{\circledR}$ FL Autofluorescence microscope. A representative image of the assay is shown. Scale bar $=50 \mu \mathrm{m}$. b, c Quantification of the proportion of dead cells compared to the total cells in WT (in b) and 5xFAD cultures (in c). Total number of cells counted (number of dead cells counted in brackets) was as follows in WT: $n=1183(439), 1070(472), 650(314), 813(318)$, 797(400), and 5xFAD: $n=528(212), 640(270), 1019(442), 465(224)$, 775(544) for NT, control (equivalent of $1 \mu \mathrm{M}$ ), control (equivalent of $5 \mu \mathrm{M})$, hexameric $\mathrm{A} \beta(1 \mu \mathrm{M})$, and hexameric $\mathrm{A} \beta(5 \mu \mathrm{M})$ respectively. $N T$ not treated. $N=4$ independent experiments in WT, $N=3$ independent experiments in 5xFAD. One-way ANOVA with Tukey's multiple comparison test: $n s$ non-significant, $* p<0.05$, $* * p<0.01$ (in WT: $p=0.99$ NT vs hexameric A $\beta(1 \mu \mathrm{M}), p=0.38$ NT vs hexameric $\mathrm{A} \beta(5 \mu \mathrm{M}), p=0.95$ control $(1 \mu \mathrm{M})$ vs hexameric $\mathrm{A} \beta(1 \mu \mathrm{M})$, $p=0.97$ control $(5 \mu \mathrm{M})$ vs hexameric $\mathrm{A} \beta(5 \mu \mathrm{M})$; in $5 \mathrm{xFAD}: p=0.70$ NT vs hexameric $\mathrm{A} \beta(1 \mu \mathrm{M}), p=0.004 \mathrm{NT}$ vs hexameric $\mathrm{A} \beta(5 \mu \mathrm{M})$, $p=0.85$ control $(1 \mu \mathrm{M})$ vs hexameric $\mathrm{A} \beta(1 \mu \mathrm{M})$, and $p=0.009$ control $(5 \mu \mathrm{M})$ vs hexameric $\mathrm{A} \beta(5 \mu \mathrm{M}))$ 


\section{Declarations}

Conflict of interest The authors declare that the research was conducted in the absence of any commercial or financial relationships that could be construed as a potential conflict of interest.

Ethical Approval All animal experiments were performed with the approval of the UCLouvain Ethical Committee for Animal Welfare (Reference 2018/UCL/MD/011). Human cerebrospinal fluid samples were collected as part of clinical analyses performed at Cliniques Universitaires Saint-Luc (UCL, Brussels, Belgium).

Informed Consent Symptomatic non-AD patients signed an internal regulatory document, stating that residual samples used for diagnostic procedures can be used for retrospective academic studies, without any additional informed consent (ethics committee approval: 2007/10SEP/233). AD patients participated to a specific study referenced UCL-2016-121 (Eudra-CT: 2018-003473-94).

Consent for Publication All authors have given consent for publication.

Open Access This article is licensed under a Creative Commons Attribution 4.0 International License, which permits use, sharing, adaptation, distribution and reproduction in any medium or format, as long as you give appropriate credit to the original author(s) and the source, provide a link to the Creative Commons licence, and indicate if changes were made. The images or other third party material in this article are included in the article's Creative Commons licence, unless indicated otherwise in a credit line to the material. If material is not included in the article's Creative Commons licence and your intended use is not permitted by statutory regulation or exceeds the permitted use, you will need to obtain permission directly from the copyright holder. To view a copy of this licence, visit http://creativecommons.org/licenses/by/4.0/.

\section{References}

1. Haass C, Kaether C, Thinakaran G, Sisodia S (2012) Trafficking and proteolytic processing of APP. Cold Spring Harb Perspect Med 2(5):a006270. https://doi.org/10.1101/cshperspect.a006270

2. Takami M, Nagashima Y, Sano Y, Ishihara S, MorishimaKawashima M, Funamoto S, Ihara Y (2009) gamma-Secretase: successive tripeptide and tetrapeptide release from the transmembrane domain of beta-carboxyl terminal fragment. J Neurosci 29(41):13042-13052. https://doi.org/10.1523/jneurosci.2362-09. 2009

3. Bitan G, Kirkitadze MD, Lomakin A, Vollers SS, Benedek GB, Teplow DB (2003) Amyloid beta -protein (Abeta) assembly: Abeta 40 and Abeta 42 oligomerize through distinct pathways. Proc Natl Acad Sci USA 100(1):330-335. https://doi.org/10.1073/ pnas.222681699

4. Benilova I, Karran E, De Strooper B (2012) The toxic A $\beta$ oligomer and Alzheimer's disease: an emperor in need of clothes. Nat Neurosci 15(3):349-357. https://doi.org/10.1038/nn.3028

5. Almeida ZL, Brito RMM (2020) Structure and aggregation mechanisms in amyloids. Molecules. https://doi.org/10.3390/molec ules25051195

6. Sengupta U, Nilson AN, Kayed R (2016) The role of amyloid- $\beta$ oligomers in toxicity, propagation, and immunotherapy. EBioMedicine 6:42-49. https://doi.org/10.1016/j.ebiom.2016.03.035

7. Ye L, Fritschi SK, Schelle J, Obermüller U, Degenhardt K, Kaeser SA, Eisele YS, Walker LC, et al (2015) Persistence of A $\beta$ seeds in APP null mouse brain. Nat Neurosci 18(11):1559-1561. https:// doi.org/10.1038/nn.4117
8. Wolff M, Zhang-Haagen B, Decker C, Barz B, Schneider M, Biehl R, Radulescu A, Strodel B, et al (2017) A $\beta 42$ pentamers/hexamers are the smallest detectable oligomers in solution. Sci Rep 7(1):2493. https://doi.org/10.1038/s41598-017-02370-3

9. Ferrone F (1999) Analysis of protein aggregation kinetics. Methods Enzymol 309:256-274. https://doi.org/10.1016/s00766879(99)09019-9

10. Serpell LC (2000) Alzheimer's amyloid fibrils: structure and assembly. Biochim Biophys Acta 1502(1):16-30. https://doi.org/ 10.1016/s0925-4439(00)00029-6

11. Roychaudhuri R, Yang M, Hoshi MM, Teplow DB (2009) Amyloid beta-protein assembly and Alzheimer disease. J Biol Chem 284(8):4749-4753. https://doi.org/10.1074/jbc.R800036200

12. Cernescu M, Stark T, Kalden E, Kurz C, Leuner K, Deller T, Göbel M, Eckert GP, et al (2012) Laser-induced liquid bead ion desorption mass spectrometry: an approach to precisely monitor the oligomerization of the $\beta$-amyloid peptide. Anal Chem 84(12):5276-5284. https://doi.org/10.1021/ac300258m

13. Österlund N, Moons R, Ilag LL, Sobott F, Gräslund A (2019) Native ion mobility-mass spectrometry reveals the formation of $\beta$-barrel shaped amyloid- $\beta$ hexamers in a membrane-mimicking environment. J Am Chem Soc 141(26):10440-10450. https://doi. org/10.1021/jacs.9b04596

14. Decock M, Stanga S, Octave JN, Dewachter I, Smith SO, Constantinescu SN, Kienlen-Campard P (2016) Glycines from the APP GXXXG/GXXXA transmembrane motifs promote formation of pathogenic a $\beta$ oligomers in cells. Front Aging Neurosci 8:107. https://doi.org/10.3389/fnagi.2016.00107

15. Vadukul DM, Vrancx C, Burguet P, Contino S, Suelves N, Serpell LC, Quinton L, Kienlen-Campard P (2021) An evaluation of the self-assembly enhancing properties of cell-derived hexameric amyloid- $\beta$. Sci Rep 11(1):11570. https://doi.org/10.1038/ s41598-021-90680-y

16. De Strooper B (2003) Aph-1, Pen-2, and nicastrin with presenilin generate an active gamma-Secretase complex. Neuron 38(1):9-12. https://doi.org/10.1016/s0896-6273(03)00205-8

17. De Strooper B, Saftig P, Craessaerts K, Vanderstichele H, Guhde G, Annaert W, Von Figura K, Van Leuven F (1998) Deficiency of presenilin-1 inhibits the normal cleavage of amyloid precursor protein. Nature 391(6665):387-390. https://doi.org/10.1038/ 34910

18. Frånberg J, Svensson AI, Winblad B, Karlström H, Frykman S (2011) Minor contribution of presenilin 2 for $\gamma$-secretase activity in mouse embryonic fibroblasts and adult mouse brain. Biochem Biophys Res Commun 404(1):564-568. https://doi.org/10.1016/j. bbrc.2010.12.029

19. Pintchovski SA, Schenk DB, Basi GS (2013) Evidence that enzyme processivity mediates differential A $\beta$ production by PS 1 and PS2. Curr Alzheimer Res 10(1):4-10. https://doi.org/10.2174/ 156720513804871480

20. Xia D, Watanabe H, Wu B, Lee SH, Li Y, Tsvetkov E, Bolshakov VY, Shen J, et al (2015) Presenilin-1 knockin mice reveal lossof-function mechanism for familial Alzheimer's disease. Neuron 85(5):967-981. https://doi.org/10.1016/j.neuron.2015.02.010

21. Stanga S, Vrancx C, Tasiaux B, Marinangeli C, Karlström H, Kienlen-Campard P (2018) Specificity of presenilin-1- and presenilin-2-dependent $\gamma$-secretases towards substrate processing. J Cell Mol Med 22(2):823-833. https://doi.org/10.1111/jcmm. 13364

22. Meckler X, Checler F (2016) Presenilin 1 and Presenilin 2 target $\gamma$-secretase complexes to distinct cellular compartments. J Biol Chem 291(24):12821-12837. https://doi.org/10.1074/jbc.M115. 708297

23. Sannerud R, Esselens C, Ejsmont P, Mattera R, Rochin L, Tharkeshwar AK, De Baets G, De Wever V, et al (2016) Restricted location of PSEN $2 / \gamma$-secretase determines substrate specificity and 
generates an intracellular A $\beta$ pool. Cell 166(1):193-208. https:// doi.org/10.1016/j.cell.2016.05.020

24. Lambert MP, Barlow AK, Chromy BA, Edwards C, Freed R, Liosatos M, Morgan TE, Rozovsky I, et al (1998) Diffusible, nonfibrillar ligands derived from Abeta1-42 are potent central nervous system neurotoxins. Proc Natl Acad Sci USA 95(11):6448-6453. https://doi.org/10.1073/pnas.95.11.6448

25. Lesné S, Koh MT, Kotilinek L, Kayed R, Glabe CG, Yang A, Gallagher M, Ashe KH (2006) A specific amyloid-beta protein assembly in the brain impairs memory. Nature 440(7082):352357. https://doi.org/10.1038/nature04533

26. Müller-Schiffmann A, Herring A, Abdel-Hafiz L, Chepkova AN, Schäble S, Wedel D, Horn AH, Sticht H, et al (2016) Amyloid- $\beta$ dimers in the absence of plaque pathology impair learning and synaptic plasticity. Brain 139(Pt 2):509-525. https://doi.org/10. 1093/brain/awv355

27. Shankar GM, Li S, Mehta TH, Garcia-Munoz A, Shepardson NE, Smith I, Brett FM, Farrell MA, et al (2008) Amyloid-beta protein dimers isolated directly from Alzheimer's brains impair synaptic plasticity and memory. Nat Med 14(8):837-842. https://doi.org/ 10.1038/nm1782

28. Townsend M, Shankar GM, Mehta T, Walsh DM, Selkoe DJ (2006) Effects of secreted oligomers of amyloid beta-protein on hippocampal synaptic plasticity: a potent role for trimers. J Physiol 572(Pt 2):477-492. https://doi.org/10.1113/jphysiol.2005. 103754

29. Oakley H, Cole SL, Logan S, Maus E, Shao P, Craft J, GuillozetBongaarts A, Ohno M, et al (2006) Intraneuronal beta-amyloid aggregates, neurodegeneration, and neuron loss in transgenic mice with five familial Alzheimer's disease mutations: potential factors in amyloid plaque formation. J Neurosci 26(40):10129-10140. https://doi.org/10.1523/jneurosci.1202-06.2006

30. Kienlen-Campard P, Tasiaux B, Van Hees J, Li M, Huysseune S, Sato T, Fei JZ, Aimoto S, et al (2008) Amyloidogenic processing but not amyloid precursor protein (APP) intracellular $\mathrm{C}$-terminal domain production requires a precisely oriented APP dimer assembled by transmembrane GXXXG motifs. J Biol Chem 283(12):7733-7744. https://doi.org/10.1074/jbc.M707142200

31. Huysseune S, Kienlen-Campard P, Hébert S, Tasiaux B, Leroy K, Devuyst O, Brion JP, De Strooper B, et al (2009) Epigenetic control of aquaporin 1 expression by the amyloid precursor protein. FASEB J 23(12):4158-4167. https://doi.org/10.1096/fj.09-140012

32. Karlström H, Bergman A, Lendahl U, Näslund J, Lundkvist J (2002) A sensitive and quantitative assay for measuring cleavage of presenilin substrates. J Biol Chem 277(9):6763-6766. https:// doi.org/10.1074/jbc.C100649200

33. Marshall KE, Vadukul DM, Dahal L, Theisen A, Fowler MW, AlHilaly Y, Ford L, Kemenes G, et al (2016) A critical role for the self-assembly of Amyloid- $\beta 1-42$ in neurodegeneration. Sci Rep 6:30182. https://doi.org/10.1038/srep30182

34. Hsu PD, Lander ES, Zhang F (2014) Development and applications of CRISPR-Cas9 for genome engineering. Cell 157(6):12621278. https://doi.org/10.1016/j.cell.2014.05.010

35. Wiedenheft B, Sternberg SH, Doudna JA (2012) RNA-guided genetic silencing systems in bacteria and archaea. Nature 482(7385):331-338. https://doi.org/10.1038/nature10886

36. Hage S, Stanga S, Marinangeli C, Octave JN, Dewachter I, QuetinLeclercq J, Kienlen-Campard P (2015) Characterization of Pterocarpus erinaceus kino extract and its gamma-secretase inhibitory properties. J Ethnopharmacol 163:192-202. https://doi.org/10. 1016/j.jep.2015.01.028

37. Marinangeli C, Tasiaux B, Opsomer R, Hage S, Sodero AO, Dewachter I, Octave JN, Smith SO, et al (2015) Presenilin transmembrane domain 8 conserved AXXXAXXXG motifs are required for the activity of the $\gamma$-secretase complex. J Biol Chem 290(11):7169-7184. https://doi.org/10.1074/jbc.M114.601286
38. Teunissen CE, Petzold A, Bennett JL, Berven FS, Brundin L, Comabella M, Franciotta D, Frederiksen JL, et al (2009) A consensus protocol for the standardization of cerebrospinal fluid collection and biobanking. Neurology 73(22):1914-1922. https://doi. org/10.1212/WNL.0b013e3181c47cc2

39. Opsomer R, Contino S, Perrin F, Gualdani R, Tasiaux B, Doyen $\mathrm{P}$, Vergouts M, Vrancx C, et al (2020) Amyloid precursor protein (APP) controls the expression of the transcriptional activator neuronal PAS domain protein 4 (NPAS4) and synaptic GABA release. eNeuro. https://doi.org/10.1523/eneuro.0322-19.2020

40. Munter LM, Voigt P, Harmeier A, Kaden D, Gottschalk KE, Weise C, Pipkorn R, Schaefer M, et al (2007) GxxxG motifs within the amyloid precursor protein transmembrane sequence are critical for the etiology of Abeta42. EMBO J 26(6):1702-1712. https:// doi.org/10.1038/sj.emboj.7601616

41. Dehury B, Tang N, Blundell TL, Kepp KP (2019) Structure and dynamics of $\gamma$-secretase with presenilin 2 compared to presenilin 1. RSC Adv 9(36):20901-20916. https://doi.org/10.1039/C9RA0 $2623 \mathrm{~A}$

42. Lauritzen I, Pardossi-Piquard R, Bourgeois A, Pagnotta S, Biferi MG, Barkats M, Lacor P, Klein W, et al (2016) Intraneuronal aggregation of the $\beta$-CTF fragment of APP (C99) induces $\mathrm{A} \beta$-independent lysosomal-autophagic pathology. Acta Neuropathol 132(2):257-276. https://doi.org/10.1007/ s00401-016-1577-6

43. Evrard C, Kienlen-Campard P, Coevoet M, Opsomer R, Tasiaux B, Melnyk P, Octave JN, Buée L, et al (2018) Contribution of the endosomal-lysosomal and proteasomal systems in amyloid- $\beta$ precursor protein derived fragments processing. Front Cell Neurosci 12:435. https://doi.org/10.3389/fncel.2018.00435

44. Perrin F, Papadopoulos N, Suelves N, Opsomer R, Vadukul DM, Vrancx C, Smith SO, Vertommen D, et al (2020) Dimeric transmembrane orientations of APP/C99 regulate $\gamma$-secretase processing line impacting signaling and oligomerization. ISCIENCE. https://doi.org/10.1016/j.isci.2020.101887

45. Rajendran L, Honsho M, Zahn TR, Keller P, Geiger KD, Verkade P, Simons K (2006) Alzheimer's disease beta-amyloid peptides are released in association with exosomes. Proc Natl Acad Sci USA 103(30):11172-11177. https://doi.org/10.1073/pnas.06038 38103

46. Eimer WA, Vassar R (2013) Neuron loss in the 5XFAD mouse model of Alzheimer's disease correlates with intraneuronal A $\beta 42$ accumulation and Caspase-3 activation. Mol Neurodegener 8:2. https://doi.org/10.1186/1750-1326-8-2

47. Doecke JD, Pérez-Grijalba V, Fandos N, Fowler C, Villemagne VL, Masters CL, Pesini P, Sarasa M (2020) Total A $\beta(42) / A \beta(40)$ ratio in plasma predicts amyloid-PET status, independent of clinical AD diagnosis. Neurology 94(15):e1580-e1591. https://doi. org/10.1212/wnl.0000000000009240

48. Gravina SA, Ho L, Eckman CB, Long KE, Otvos L, Younkin LH, Suzuki N, Younkin SG (1995) Amyloid beta protein (A beta) in Alzheimer's disease brain. Biochemical and immunocytochemical analysis with antibodies specific for forms ending at A beta 40 or A beta 42(43). J Biol Chem 270(13):7013-7016. https://doi.org/ $10.1074 /$ jbc. 270.13 .7013

49. Jarrett JT, Berger EP, Lansbury PT Jr (1993) The carboxy terminus of the beta amyloid protein is critical for the seeding of amyloid formation: implications for the pathogenesis of Alzheimer's disease. Biochemistry 32(18):4693-4697. https://doi.org/10.1021/ bi00069a001

50. Li X, Buxbaum JN (2011) Transthyretin and the brain re-visited: is neuronal synthesis of transthyretin protective in Alzheimer's disease? Mol Neurodegener 6:79. https://doi.org/10.1186/ 1750-1326-6-79

51. Kim H, Kim B, Kim HS, Cho JY (2020) Nicotinamide attenuates the decrease in dendritic spine density in hippocampal primary 
neurons from 5xFAD mice, an Alzheimer's disease animal model. Mol Brain 13(1):17. https://doi.org/10.1186/s13041-020-0565-x

52. Mariani MM, Malm T, Lamb R, Jay TR, Neilson L, Casali B, Medarametla L, Landreth GE (2017) Neuronally-directed effects of RXR activation in a mouse model of Alzheimer's disease. Sci Rep 7:42270. https://doi.org/10.1038/srep42270

53. Noh H, Park C, Park S, Lee YS, Cho SY, Seo H (2014) Prediction of miRNA-mRNA associations in Alzheimer's disease mice using network topology. BMC Genomics 15(1):644. https://doi.org/10. 1186/1471-2164-15-644

54. Roychaudhuri R, Yang M, Deshpande A, Cole GM, Frautschy S, Lomakin A, Benedek GB, Teplow DB (2013) C-terminal turn stability determines assembly differences between $\mathrm{A} \beta 40$ and $\mathrm{A} \beta 42$. J Mol Biol 425(2):292-308. https://doi.org/10.1016/j.jmb.2012. 11.006

55. Lendel C, Bjerring M, Dubnovitsky A, Kelly RT, Filippov A, Antzutkin ON, Nielsen NC, Härd T (2014) A hexameric peptide barrel as building block of amyloid- $\beta$ protofibrils. Angew Chem Int Ed Engl 53(47):12756-12760. https://doi.org/10.1002/anie. 201406357

56. Bayer TA, Wirths $O$ (2011) Intraneuronal $A \beta$ as a trigger for neuron loss: can this be translated into human pathology? Biochem Soc Trans 39(4):857-861. https://doi.org/10.1042/bst0390857

57. Friedrich RP, Tepper K, Rönicke R, Soom M, Westermann M, Reymann K, Kaether C, Fändrich M (2010) Mechanism of amyloid plaque formation suggests an intracellular basis of Abeta pathogenicity. Proc Natl Acad Sci USA 107(5):1942-1947. https://doi.org/10.1073/pnas.0904532106

58. Gouras GK, Tampellini D, Takahashi RH, Capetillo-Zarate E (2010) Intraneuronal beta-amyloid accumulation and synapse pathology in Alzheimer's disease. Acta Neuropathol 119(5):523541. https://doi.org/10.1007/s00401-010-0679-9

59. Pensalfini A, Albay R 3rd, Rasool S, Wu JW, Hatami A, Arai H, Margol L, Milton S, et al (2014) Intracellular amyloid and the neuronal origin of Alzheimer neuritic plaques. Neurobiol Dis 71:53-61. https://doi.org/10.1016/j.nbd.2014.07.011

60. Jack CR Jr, Knopman DS, Jagust WJ, Shaw LM, Aisen PS, Weiner MW, Petersen RC, Trojanowski JQ (2010) Hypothetical model of dynamic biomarkers of the Alzheimer's pathological cascade. Lancet Neurol 9(1):119-128. https://doi.org/10.1016/s14744422(09)70299-6

61. Castelletto V, Ryumin P, Cramer R, Hamley IW, Taylor M, Allsop D, Reza M, Ruokolainen J, et al (2017) Self-assembly and Antiamyloid cytotoxicity activity of amyloid beta peptide derivatives. Sci Rep 7:43637. https://doi.org/10.1038/srep43637

62. Morales R, Callegari K, Soto C (2015) Prion-like features of misfolded $\mathrm{A} \beta$ and tau aggregates. Virus Res 207:106-112. https://doi. org/10.1016/j.virusres.2014.12.031

63. Katzmarski N, Ziegler-Waldkirch S, Scheffler N, Witt C, AbouAjram C, Nuscher B, Prinz M, Haass C, et al (2020) A $\beta$ oligomers trigger and accelerate $A \beta$ seeding. Brain Pathol 30(1):36-45. https://doi.org/10.1111/bpa.12734

Publisher's Note Springer Nature remains neutral with regard to jurisdictional claims in published maps and institutional affiliations. 